\title{
COLORADOSCHOOLOFMINES
}

EARTH•ENERGY•ENVIRONMENT

Division OF ECONOMICS AND BUSINESS

WORKING PAPER SERIES

\section{Cyclical and Secular Determinants of Productivity in the Copper, Aluminum, Iron Ore, and Coal Industries}

John E. Tilton

\author{
Working Paper 2013-11 \\ http://econbus.mines.edu/working-papers/wp201311.pdf \\ Colorado School of Mines \\ Division of Economics and Business \\ 1500 Illinois Street \\ Golden, CO 80401
}

November 2013

(c) 2013 by the listed authors. All rights reserved. 
Colorado School of Mines

Division of Economics and Business

Working Paper No. 2013-11

November 2013

Title:

Cyclical and Secular Determinants of Productivity in the Copper, Aluminum, Iron Ore, and Coal Industries*

Author(s):

John E. Tilton

Division of Economics and Business

Colorado School of Mines

Golden, CO 80401-1887

jtilton@mines.edu

\begin{abstract}
Over the past decade both labor and multifactor productivity have fallen in copper, iron ore, coal, and many other mining operations, causing production costs to rise. This decline, following years of rising productivity, has led many to conclude that new technology can no longer offset the adverse effects of resource depletion. As a result, real mineral commodity prices will be permanently higher in the future.

This article questions this hypothesis. It first provides a conceptual analysis that shows that much or perhaps even all of the recent drop in productivity could be due to the unanticipated growth in market demand and the sharp jump in prices it provoked. It then surveys a number of the available empirical studies of productivity trends. For copper, iron ore, and coal, it finds substantial support for the view that much of the recent drop in productivity can be attributed to higher prices. Aluminum on the other hand did not experience the same jump in real price over the 2000s. Nor did it suffer a significant drop in productivity.

These findings have important implications. In particular, they suggest that new technology may well continue to offset most or all of the cost-increasing effects of resource depletion. If so, real commodity prices will be lower over the long run than many now assume. This possibility has important consequences for mineral producing firms making large investments in future capacity, for mineral producing countries dependent on revenues from mining, and for society as a whole in terms of the long-run availability of nonrenewable commodities and the future threat of mineral depletion.
\end{abstract}

\title{
$J E L$ classifications: L71, L72, O3, Q3, Q4
}

Keywords: mineral productivity_trends and determinants, copper, aluminum, iron ore, coal

*John E. Tilton (jtilton@mines.edu) is a Research Professor of Economics and Business at the Colorado School of Mines and a Professor in the Mining Engineering Department in the School of Engineering at the Catholic University of Chile. He is grateful to Rio Tinto Economics \& Markets for its financial support and permission to publish this study and to David Humphreys and Marian Radetzki for their thoughtful comments. 


\section{INTRODUCTION}

Over the past decade productivity in mining has fallen around the world. Both the size of the decline and the fact that it follows on the heels of some two decades of rising productivity have accentuated the concern over this development. Falling productivity means that more labor, capital, energy, and other inputs are needed to mine and process a ton of copper, aluminum, iron ore, or coal. This in turn pushes production costs up and eventually mineral commodity prices up as well.

Many contend that this is the new reality for nonrenewable resources. The benevolent past trends of rising productivity and falling real costs and prices, it is argued, have come to an end thanks largely to two new developments. The first is the depletion of high quality mineral resources and our inability to find comparable replacements. As a result, society must now rely on lower grade and more costly deposits. The depletion of our high quality resources has accelerated over the past decade thanks largely to China's rapid economic development and the strain on mineral commodity production that it has fostered. Even if economic growth in China slows, a likely possibility, growth in global mineral production is likely to remain brisk as India, Brazil, and other developing countries take up the slack.

The second development adversely affecting productivity, costs, and prices is the decline in the pace at which new, cost-reducing innovations arise and diffuse in mining. In the past, new technology has offset the cost-increasing effects of mineral depletion. In the future, this is not likely to be the case in part because (as just noted) depletion is becoming more severe and in part because the easy technological advances have been made. 
This school of thought, of course, has not gone unchallenged. Past prophecies regarding declining opportunities to innovate and develop new technologies have failed to materialize. Moreover, some of the recent decline in productivity and rise in costs is clearly cyclical, rather than long-term or secular, in nature. The surge in mineral commodity prices, for example, has allowed high-cost mines with low productivity to enter the mining industry or to remain in operation. Still, high mineral commodity prices over most of the past decade coupled with their quick and dramatic recovery in 2010 following the worse recession in the industrial world since the Great Depression lends support to those who maintain trends in productivity, costs, and prices are now traveling a new course.

\section{Purpose}

This study explores this issue and in the process addresses the following questions:

- What have been the important causes for the recent collapse in mining productivity?

- Are the causes largely cyclical or secular in nature? Should we expect the historical trends of rising productivity and falling real costs to return when mineral commodity prices decline?

- What is the nature of cause and effect between mineral commodity prices and productivity? In particular, do changes in mineral commodity prices have an important influence on mining productivity in the short run, while cause and effect runs in the opposite direction in the long run? That is, over the long run are changes in mining productivity a major determinant of mineral commodity prices?

- How does the quality of the mineral resources being exploited change over time and why? Does depletion have a cyclical as well as secular influence on mining productivity? 
- Similarly, do innovation and technological change have a cyclical as well as secular influence on mining productivity?

\section{Importance}

These are important questions for firms and countries that produce mineral commodities, for those that consume mineral commodities, and for human society as a whole. As the Nobel laureate Paul Krugman (1994, p. 13) once noted:

Productivity isn't everything, but in the long run it is almost everything. A country's ability to improve its standard of living over time depends almost entirely on its ability to raise its output per worker.

We also know that the long-run threat posed by mineral depletion to modern civilization depends largely on a race between the cost-increasing effects of having to rely on poorer grade, more remote, and more-difficult-to-process resources and the cost-reducing effects of new technology. Over the past century or two, despite the dramatic explosion in mineral resource extraction, new technology has successfully kept the cost-increasing effects of depletion at bay. There is, of course, no guarantee this favorable situation will continue indefinitely into the future. Indeed, if the recent drop in mining productivity reflects a long-run, secular trend, this implies that new technology is now struggling to offset the adverse effects of depletion.

Mining productivity also has important implications for the terms of trade of mineral producing countries, such as Australia, Canada, Chile, Peru, Mongolia, Russia, and others. Over half a century ago, Raul Prebisch (1949) and Hans Singer (1950), working independently, published two very influential articles, in which they argued that the terms of trade (the ratio of the prices of a country's exports to 
the prices of its imports) of primary product exporting countries fall over time. Their work provided the intellectual basis for the autarkic economic policies introduced by many developing countries during the 1960s and 1970s, most of which produced disappointing results. It also set off a debate over the terms of trade of primary product producing countries that continues to this day. If the recent decline in mining productivity is secular rather than cyclical, the favorable shift in the terms of trade toward mineral exporting countries could persist for some time.

Finally, an understanding of the determinants of the recent decline in mining productivity and the extent to which they are secular and cyclical is crucial for both producers and consumers of mineral products. This is because productivity trends (along with factor input prices) determine the costs of producing mineral commodities and their prices. As a result, forecasting future prices in the short run (the next year or two), in the long run (over the next several decades), and in between requires a good understanding of productivity trends.

\section{Methodology, Scope, and Organization}

In analyzing the recent decline in mining productivity and the questions posed above, this study employs a two-step methodology. The first step entails a conceptual analysis, the objective of which is to identify the causes of the recent decline in mining productivity along with the cyclical and secular nature of their potential influence. The second step then attempts to assess their actual influenceand the extent to which that influence is cyclical and secular-for the copper, 
aluminum, iron ore, and coal industries on the basis of a review of the existing literature.

Section III, which follows this introduction, provides the conceptual analysis. Sections IV, V, VI, and VII contain the literature surveys for copper, aluminum, iron ore, and coal respectively. Section VIII highlights the conclusions and examines their implications. Section IX provides the references for works cited in the report, while Section X provides a list of productivity studies of particular relevance for understanding mining productivity.

\section{PRODUCTIVITY AND ITS DETERMINANTS: A CONCEPTUAL OVERVIEW}

The output $\left(Q_{t}\right)$ of a mine, firm, or industry, as shown in the highly generalized production function below (equation 1), can vary over time due to changes in factor inputs-labor $\left(\mathrm{L}_{\mathrm{t}}\right)$, capital $\left(\mathrm{K}_{\mathrm{t}}\right)$, and intermediate goods $\left(\mathrm{M}_{\mathrm{t}}\right)$ - or to changes in the efficiency $\left(A_{t}\right)$ with which these inputs are converted into output. Of course, changes in inputs and changes in the efficiency with which they are converted to output are not mutually exclusive, and normally over time both types of changes are taking place. The notation $\mathrm{f}($.$) in equations 1$ and 2 simply reflects an unspecified production function that indicates how much output can be produced from any given combination of labor, capital, and intermediated goods at a prescribed level of efficiency.

$$
Q_{t}=A_{t} f\left(L_{t}, K_{t}, M_{t}\right)
$$




$$
A_{t}=Q_{t} / f\left(L_{t}, K_{t}, M_{t}\right)
$$

The efficiency $\left(A_{t}\right)$ with which inputs are converted into output is referred to as multifactor productivity (MFP) or total factor productivity (TFP). Here we will use the term multifactor productivity or MFP as it is somewhat more widely used.

Estimating trends in MFP is fraught with measurement problems. ${ }^{2}$ The following are just a few examples: How to measure output, particularly when a mine or firm produces more than one product? How to estimate the capital stock given depreciation and the historical pattern of past investment? And then, how to measure the capital input over a given time period such as a year from estimates of the capital stock? How to combine the factor inputs to estimate the denominator on the right hand side of equation 2? Fortunately, scholars and others have over the years devoted considerable effort to addressing these challenges, allowing us to have some confidence in the existing studies of MFP in mining and other industries.

There are, of course, other measures of productivity than MFP. The most common is labor productivity (LP) or the ratio of output per unit of labor input $\left(Q_{t} / L_{t}\right)$. LP is usually much easier to estimate with far fewer measurement challenges than MFP. Moreover, for some purposes, such as assessing the impact of productivity changes on living standards, LP can be more useful and relevant. However, LP can rise of fall because the amount of capital or energy available per worker increases or declines, and so may not reflect changes in efficiency. In practice, though, trends in LP often follow those of MFP.

\footnotetext{
${ }^{2}$ See Syverson (2011) for a fuller description of the measurement issues encountered in calculating MFP.
} 


\section{Determinants of Labor and Multifactor Productivity}

For our purposes, it is useful to separate the many factors influencing productivity into several different groups or classes-innovation and technological change, resource depletion and ore quality, government regulations, labor quality, investment lags, economies of scale, capacity utilization, strikes and other unplanned outages, and all other factors.

1. Innovation and technological change.

This group of determinants covers a wide range of activities, all of which allow mines and companies to produce more output with the same amount of input. Innovation may entail a major technological breakthrough, such as solventextraction electrowinning in copper production or longwall mining in underground coal operations. Major innovations, such as these, are normally followed by numerous, more minor innovations. Individually these advances make small improvements on the original development, but their collective impact on productivity can be substantial.

Information technology has over the past decade or two received a great deal of attention for its positive effects on productivity across the entire economy including mining. Mine planning, maintenance, and truck scheduling are just a few of the mining operations that in recent years have been revolutionized by new computational hardware and software.

Then, there are many innovations that do not advance technology at all. They may simply reflect changes in management and work practices, such as allowing a 
machine operator to carry out routine maintenance or finding ways to get along with fewer receptionists or security personnel.

Technological change, it is useful to note, can be embodied or disembodied. Embodied technological change is coupled with capital expenditures. It requires producers invest in new equipment or even completely new processing facilities to capture its benefits. The introduction of much larger trucks, shovels, and drills, for example, has greatly increased the productivity of open cast mining over the past 50 years. To capture the benefits associated with these advances, however, mines have had to replace their old trucks, shovels, and drills. On the other hand, the new and better explosives developed over the same period reflect disembodied technological change, as they are not embodied in equipment and so can be employed without major new capital investments.

Another activity in this group of determinants is learning by doing. Every mine in some respects is unique. The extraction and processing of its ores takes skills that improve as workers and managers gain experience. We normally associate learning by doing with high-tech industries, such as aircraft production and semiconductor manufacturing. However, it can be important in mining as well, reflecting the fact that mining is more high tech than widely recognized.

2. Resource depletion and ore quality

Our second important determinant is the quality of the ore or resource. One might argue that the resource being exploited is another input, just like labor, capital, and intermediate inputs, and should be included along with these inputs in equations 1 and 2. In this case, the estimated MFP would reflect the efficiency with 
which all inputs, including resources of a given quality, were being converted into output. In practice, however, it is difficult to obtain good data on ore quality. As a result, most studies that consider resource quality treat it as a determinant of mining productivity. ${ }^{3}$ This procedure, it is important to note, means that the estimated trends in LP and MFP tend to underestimate changes in efficiency when resource quality is falling.

\section{Government regulations}

Government policies, rules, and regulations can affect productivity. Environmental regulations, for example, increase the inputs needed to produce a given output, reducing productivity. Worker health and safety regulations may do the same, though such regulations if they reduce the lost production associated with accidents sufficiently may enhance productivity.

4. Worker quality

Changing labor quality—for example, increases or decreases in average worker education or experience—often affect mining productivity. One might account for such changes by adjusting labor inputs (e.g., the number of hours worked) upward when quality is improving and downward when it is declining. In practice, however, it is difficult to estimate quality-adjusted labor input. So, normally changes in labor quality are treated as a determinant of mining productivity.

\section{Investment lags}

\footnotetext{
3 There are a few exceptions, including Topp et al. (2008), that attempt to measure changes in ore quality and to assess its specific influence on productivity. See Topp et al. (2008, Box 3.1) for a description of such studies.
} 
New mines and processing facilities often take several years or more to construct, while a decade or more may pass before new discoveries from exploration are brought on stream. These investments, however, are normally counted as capital inputs from the time they are made. As a result, MFP (though not LP, as it does not take into account changes in capital inputs) may fall for a number of years after a surge in new investment. Similarly, if firms cut back on their investments in exploration and new capacity, MFP will rise for a time as the reduction in capital input is immediate while the effect on production is delayed.

\section{Economies of scale}

Economies of scale reduce per unit production costs as output increases. At some point, however, the inefficiencies associated with larger operations offset the benefits, and at this point diseconomies of scale set in. In most industries there is a natural tendency for plant and firm size to gravitate toward the optimal scale. In mining, however, the estimated reserves of a deposit and other features of the underlying ore body may impede this tendency.

\section{Capacity utilization}

Mine costs are lowest and their productivity highest when they produce at the output level for which they were designed. If output falls below this level or is pushed above this level, productivity suffers.

8. Strikes, accidents and other unplanned production stoppages

Mine productivity declines when operations are curtailed or completely stopped due to labor strife, mine accidents, equipment failures, and inclement weather. 


\section{Other factors}

Other determinants of mining productivity that scholars and analysts have identified include management, intangible capital, firm organization, market structure and competition, and trade policy. While these factors are at times important, their influence is largely captured by one or more of the above determinants. The influence of managerial policies that motivate workers, for example, is covered by our first determinant, innovation and technological change.

\section{Cyclical and Secular Changes in Productivity}

Mining productivity follows a long-run secular trend. This trend depends largely on the extent to which innovation and new technology offset the adverse effects of resource depletion and the need to exploit lower quality resources. Other determinants in comparison are widely assumed to have second-order effects on productivity over the long run.

In the short run, mining productivity fluctuates around its long-run trend in response to mineral commodity cycles. When mineral markets are booming and prices high, mining productivity falls below its secular trend. When mineral commodity prices are depressed, just the opposite occurs. To understand the causes of these short-run fluctuations, we need once again to look at our determinants of mining productivity.

In the case of innovation and new technology, there are two (conflicting) conceptual perspectives. The first contends that innovation and technological change cause productivity to grow above trend when commodity markets are booming and vice versa. This is because producers have more resources to 
experiment with new technologies when prices and profits are high. In addition, during such periods, producers are more likely to be upgrading existing capacity and investing in new capacity, both of which facilitate the adoption of embodied technological change.

The second perspective, however, contends just the opposite is the case. The logic behind this position lies largely with the old adage that "necessity is the mother of invention." When times are tough, prices depressed, and mine survival in question, the pressure rises to reduce costs. Managers and workers become more flexible and more open to new and different ways of doing things.

These two different perspectives suggest that innovation and new technology will cause productivity to fluctuate around its secular trend over the short run. However, such fluctuations may be positively or negatively correlated with mineral commodity cycles. Which is actually the case, becomes an empirical question. As we will see, the available studies, at least in the cases of copper, aluminum, iron ore, and coal, provide considerable empirical support for the view that necessity is the mother of invention. In this case, innovation and new technology push productivity above its long-run trend when commodity markets are depressed and mines are fighting for their survival.

The influence of resource depletion and ore quality over the commodity cycle is also likely to push productivity growth above its secular trend when commodity markets are depressed. This is because some firms, when they can, modify their mine plan and exploit higher-grade ores as they struggle to lower costs and raise 
profits. At the same time, they may also reduce expenditures on overburden removal and mine development in general.

Government regulations, both with respect to the environment and worker health and safety standards, are probably best thought of as one-off or one-time influences, more or less independent of both cyclical fluctuations and the secular trend in productivity. That said, however, when commodity markets are depressed and new regulations threaten to shut down mining operations with considerable social costs to local communities and regions, governments come under great political pressure to postpone the imposition of new regulations. As a result, new government regulations reduce mining productivity more when commodity markets are strong than when they are weak.

The same applies to changes in labor quality. When commodity prices are high, firms strive to increase their output. This means hiring new workers, who on balance are younger and less experienced than the rest of their workforce. When commodity prices are depressed, firms cut production and lay off workers, keeping the best and more experienced of their employees.

Investment lags also contribute to short-run fluctuations of MFP around its secular trend (though not, as noted earlier, for fluctuations of LP). Indeed, the influence of this determinant of mining productivity is completely cyclical. When mineral markets are booming and mining firms are expanding their investments in new capacity and exploration, the lag between investment and additional output causes productivity to decline. The opposite occurs when mineral markets are 
depressed and producers cut back on their investments in exploration and new capacity.

Mines with relatively high production costs because they are too small to benefit fully from economies of scale or so large they suffer from diseconomies of scale are more likely to close, temporarily or permanently, when mineral markets are depressed. The resulting increase in economies of scale helps push mine productivity above its secular trend. Just the opposite holds, of course, when commodity markets are strong.

The influence of capacity utilization also tends to be highly cyclical. When commodity markets are depressed, mines have an incentive to reduce their output below its designed capacity, reducing productivity. Similarly, when markets are booming, efforts to push output above rated capacity are also likely to reduce mine productivity.

The influence of strikes, accidents, and other work stoppages on productivity also varies with market conditions. When prices are high, unions demand that more of the profits go to their workers in higher wages or bonuses. During such periods, unions know that the costs to companies of a work stoppage are high in terms of the lost profits. Similarly, accidents are more likely to occur when prices are high and mines are pushing the limits of their existing capacity.

For all of these reasons, much, perhaps even all, of the dramatic decline in mining productivity over the past decade may be cyclical, the result of the global boom that many mineral commodity markets have enjoyed since 2003 . This possibility raises the intriguing question of how mineral commodity prices and 
mining productivity are related. In particular, do changes in prices cause

productivity to change (as suggested above) or do changes in productivity cause prices to change (as usually assumed in economics)? The remainder of this section focuses on this question.

\section{Prices and Productivity}

Mineral product prices, like those of other commodities, are determined by supply and demand. In the short run (a period sufficiently short to preclude the addition of significant new capacity), the supply curve for mineral commodities tends to rise modestly with output until the latter approaches industry capacity. At this point, as shown in Figure 1, the slope of the supply curve turns upward and at some point becomes vertical.

The short-run demand curve for most mineral commodities is also quite steep (as shown in Figure 1) for two reasons. First, the demand for most mineral commodities is derived from the demand for the final products in which they are embedded. Since they typically account for only a small share of the total costs of the final goods in which they are used, their price can go up or down without much influence on the prices and so the demand for the final products from which their demand is derived. Second, the opportunities to substitute alterative materials for those whose prices are rising are for various reasons often limited in the short run. As a result, the short-run elasticity of demand for most mineral commodities with respect to their price is quite low, which accounts for the steep slope of their shortrun demand curve. 
Now, if a mineral industry is operating close to its capacity and so both the supply and demand curves are quite steep, a shift in either will cause a dramatic change in the market-clearing price. Commodity prices are well known for their short-run volatility. In the case of mineral products, this volatility typically arises because of shifts in the demand curve over the business cycle. (In the case of agricultural products, price volatility is normally the results of shifts in the shortrun supply curve, the result of crop failures due to pests, disease, and adverse weather conditions.)

The demand for copper, aluminum, and iron ore is quite sensitive to fluctuations in the business cycle because four end-use sectors-construction, capital equipment, automotive and transportation, and consumer durablesconsume, either directly as in the case of aluminum and copper or indirectly as in the case of iron ore, the lion's share of these commodities. These four economic sectors are well known for their cyclical gyrations. When the economy is expanding, they boom. When the economy slows, they slide into recession. In the case of coal, demand arises largely from the electric power and steel industries, whose output also tends to rise and fall with swings in the business cycle.

Figure 1 illustrates the resulting short-run instability for mineral commodity prices. When the economy is booming, the relevant short-run demand curve is $D_{b}$ and the market price is $\mathrm{P}_{\mathrm{b}}$. When the economy is in a recession, the relevant shortrun demand curve is $D_{r}$ and the market price is $\mathrm{P}_{\mathrm{r}}$.

What this simple conceptual model of short-run mineral commodity prices suggests is that, when mineral commodity markets are reasonable strong (as over 
the past decade), prices are determined largely by mineral demand and in turn the determinants of mineral demand, particularly fluctuations in GDP and the business cycle. This coupled with the numerous ways in which mineral commodity markets and prices can affect mining productivity highlighted earlier indicates that when mineral commodity markets are booming cause and effect flows over the short run from prices to productivity and not in the opposite direction.

When mineral markets and prices are depressed, however, the industry is operating on the relatively flat segment of its short-run supply curve. As a result, cause and effect between prices and productivity is likely to run in both directions. A fall in price, due for instance to a slowdown in the economy, causes productivity to rise for all the reasons discussed earlier. This reduces production costs and shifts the short-run supply curve down. This causes the market price to decline further, which in turn encourages firms to increase their productivity. In this situation, it is interesting to note, the two-direction flow of cause and effect tends to reinforce itself in a manner that accentuates a drop or rise in market price.

Over the long run, new capacity can be built. As a result, the long-run supply is not constrained by existing capacity and so no longer turns vertical at some point. Rather, as Figure 2 illustrates, at low levels of output the curve rises due to the limited number of very high quality, low cost deposits. However, as output expands necessitating the exploitation of more marginal deposits, its slope levels off and becomes relatively flat. The reason for this is that marginal deposits-for instances, copper deposits with grades of 0.4-0.5 percent copper equivalent-are much more common and easier to discover than the extraordinary deposits. 
The demand for mineral commodities in the long run is more sensitive to price than in the short run, as the long run provides more opportunities for material substitution. So the slopes of the long-run demand curves $\left(D_{1}, D_{2}\right)$ shown in Figure 2 are less steep than those shown for the short-run demand curves in Figure 1. More importantly, however, Figure 2 shows that as long as demand is sufficient to require the exploitation of marginal deposits, whether demand grows rapidly and thus reaches $D_{2}$ or slowly and so reaches only $D_{1}$, makes little impact on the long-run market equilibrium price. $\mathrm{P}_{2}$ and $\mathrm{P}_{1}$ are nearly the same. What does matter is the price at which marginal deposits become profitable to exploit. This means that productivity changes that shift the long-run supply curve, either upward or downward, can alter the market price substantially. So over the long run cause and effect runs from productivity to price.

However, the reverse is also true. Prices affect productivity over the long run by influencing the rate and direction of innovation and technological change. In particular, persistent increases in the real price of a mineral commodity, which reflect the failure of new technology to offset the effects of resource depletion, enhance the incentives for firms to develop and adopt new cost-saving technologies across the entire spectrum of production from exploration to recycling.

So in the long run, as in the short run when mineral markets are depressed, cause and effect between productivity and prices runs in both directions. There is, however, an interesting difference between these two situations. In the long run, the two-directional flow of cause and effect tends to offset, rather than reinforce, each other. For example, should falling productivity caused by resource depletion raise 
long-run production costs, this would shift the long-run supply curve and the market price up. The higher price, however, would create greater incentives to develop new innovations and technologies that increase productivity, partially or totally countering the initial decline in productivity.

To summarize, there are good reasons to believe that productivity in mining fluctuates cyclically around long-run secular trends. Over the short run, when markets are booming, cause and effect runs largely from prices to productivity. When prices rise, productivity tends to fall, and vice versa. When markets are more sluggish and excess capacity exists, cause and effect runs in both directions in a manner that accentuates the fluctuations in both prices and productivity. When prices rise, productivity tends to fall. This shifts the short-run supply curve upward, which tends to push prices even higher since the demand curve in this scenario intersects the supply curve on its relatively flat segment. Over the long run, there are also good reasons to assume that cause and effect runs in both direction between prices and productivity. However, here a rise in price encourages a rise in productivity, and so mitigates rather than accentuates the initial rise in price.

These findings raise an important empirical question: Just how important are the cyclical changes in productivity, and in particular how much of the decline in productivity in many mineral industries over the past decade can be attributed to cyclical and hence temporary fluctuations? In an attempt to provide insights on this question, the next four sections review the relevant literature for the copper, aluminum, iron ore, and coals industries.

\section{PRODUCTIVITY IN THE COPPER INDUSTRY}


The major copper mine producing countries are Chile, China, Peru, the United States, Australia, Zambia, Russia, Canada, and Indonesia. Chile alone accounts for about a third of world output, while the China, Peru, and the United States each contributes between 7 and 10 percent of the total.

The available studies of productivity in the Chilean copper mining industry are now with one exception a decade or so old, and so do not cover productivity trends during the recent boom. Nor does Jara et al. (2010), the one exception. However, data readily available from Cochilco, a Chilean government agency that annually publishes a statistical yearbook (Cochilco, annual), indicate that labor productivity in the Chilean copper industry rose from 38 tons of copper (contained in ore) per employee in 1991 to 146 tons in 2004. However, by 2012 this figure had fallen back to 100 tons.

According to Cochilco, this recent drop in labor productivity reflects very different changes among the major producing mines and companies. As Table 1 shows, productivity at Collahuasi fell by over 75 percent and at El Albra by over 50 percent between 2005 and 2010. Elsewhere the changes were also negative but more modest.

A major factor-perhaps the major factor-responsible for the drop in Chilean productivity between 2004 and 2012 was a decline in ore grade. As Table 2 notes, the copper content of the ore being mined fell from 1.11 to 0.86 percent over this period. Had ore grade remained unchanged, Chile's labor productivity would have been some 29 percent or about 29 tons per employee higher. This difference 
accounts for almost two-thirds of the 46-ton decline over this period. Some of this deterioration in ore quality is cyclical rather secular. When prices are high, lower grade operations remain profitable and are kept in operation.

Strikes and accidents have also perversely affected Chilean copper output and productivity over the past decade (Ortega Haye, 2011). A causal reading of the professional press indicates that both are largely a product of the boom in copper market. The strikes reflect attempts by organized labor to obtain for their members a bigger share of the high profits that companies have been earning. Similarly, the slope failures and other accidents are due in large part to efforts to maximize the benefits from the boom in prices by pushing existing capacity to its limits.

Using panel data for individual mines, Jara et al. (2010) attempts to look behind the trends in labor productivity and to identify the major forces shaping them. This study focuses on the period 1992-2009 and assesses copper mining in Peru as well as Chile. It finds that higher ore grades (thanks in part to the opening of new mines, particularly during the 1990s in Chile) enhanced productivity, while rising stripping ratios have had the opposite effect. It highlights, however, the overall importance of new technology and managerial improvements.

An earlier study by Garcia et al. $(2000,2001)$ also focuses on the reasons for the jump in labor productivity in the Chilean copper industry during the 1990s. In particular, it attempts to separate the contribution of improvements at existing mines_of which the most important in 1990 were Chuquicamata, Salvador, El Teniente, and Andina, the four principal mines of Codelco (the National Copper 
Corporation of Chile) - from the contribution of Escondida and the other privately owned mines that came on stream during the 1990s.

This work finds that, though the contribution of the new mines was somewhat greater than productivity improvements at existing mines, both were important. Like the Jara et al. study, it concludes that innovation and new technology played an important role in increasing Chile's labor productivity. Without these improvements, it suggests that “...many of Chile's older mines would no longer be in operation, Codelco would not be the world's largest copper producer, and copper exports from Chile would be about a third below their current level."

For our purposes, both studies provide support for the necessity-is-themother-of-invention school of thought regarding the cyclical influence of innovation and new technology on mining productivity. When Codelco was confronted with more efficient copper producers in the United States, a development we will examine shortly, and with an influx of highly efficient foreign producers on its home turf, it responded to these challenges by raising its own productivity and reducing its production costs.

Moving from Chile to the United States, one finds that the U.S. copper industry faced an even greater threat to its survival in the late 1970s and early 1980s. In 1970, the United States was the world's largest copper mining country, as had been the case throughout the $20^{\text {th }}$ century. It produced almost a third of Western World output, employed some 37,000 people, and was quite profitable. By 1985 the country's share of Western world output had fallen to 17 percent, imports 
were up, and employment down by 70 percent. Most mines were unprofitable and some were not recovering even their cash costs. In these depressed conditions, many mines curtail their production or shut down completely.

At the time many predicted the end of copper mining in the United States. Yet the industry not only survived but managed to stage a rather remarkable recovery. By 1995 output was substantially above its 1970 level, the U.S. share of western production had climbed back to 23 percent, net imports were down sharply, and producers were once again profitable.

Several published studies have examined this decline and subsequent recovery of the U.S. copper industry (Tilton and Landsberg, 1999; Aydin and Tilton, 2000; and Tilton, 2001). Their findings attribute this dramatic turnaround largely to the industry's ability to more than double labor productivity during the 1980s, thanks mostly to the introduction of new innovations and technology.

For our purposes, the experience of the U.S. copper industry during this period provides further support for the necessity-is-the-mother-of-invention school and the belief that innovation and technological change push productivity growth above its secular trend when mineral markets are depressed.

This research also shows that copper ore grades, which were declining over the longer run, rose sharply over the years 1980-1984 when the situation was darkest for the industry (Tilton and Landsberg, 1999, p. 124). This suggests that resource depletion and ore quality have a cyclical as well as secular influence on mine productivity, and do on occasions help push productivity above its secular trend when mineral markets are in the doldrums. 
Finally, this period in the history of the U.S. copper industry provides some interesting insights on labor relations. When the very survival of the industry was threatened, organized labor at many (though not all) mines became more flexible and cooperative with management, willing to accept changes in work rules and even reductions in wages. These experiences, particular when contrasted with the numerous recent confrontations between organized labor and management in Chile described earlier, indicate that labor relations can have an important cyclical influence on mine productivity.

A recent paper (Ritter et al., 2011) updates some of the earlier research on the U.S. copper industry just reviewed. It finds that labor productivity continued to rise over the 1980s and 1990s up to 2003 (though with a dip in 2000 and 2001). Between 2003 and 2008 as copper prices rose, however, productivity dropped from its peak by over 40 percent. Then, between 2008 and 2009 with the sharp dip in copper prices (due to the global economic recession that began in the latter half of 2008), labor productivity recovered, wiping out slightly more than half of its previous decline.

Studies of mining MFP in Australia and Canada (Topp et al., 2008; Bradley and Sharp, 2009) provide some interesting information on their copper industries over the recent boom. In Australia, according to Topp et al., both LP and MFP grew briskly during the 1980s and 1990s, and thereafter declined between 2 and 3 percent a year until 2006-7 (when their analysis ended). Much of the recent decline, they attribute to declining ore grades. Interestingly, copper ore grades actually rose 
from the early 1970s until the mid-1990s, but then decline by nearly 50 percent over the following decade (Topp et al., 2008, p. 53).

In the case of MFP, a second important factor causing the decline was the investment lag and the long lead times between investment and the coming on stream of new capacity. In fact, they conclude that about a third of the decline in mining MFP-all mining, not just copper mining—that occurred in Australia from 2000-01 to 2006-07 was due to the investment lag and hence cyclical in nature.

Perhaps of greater interest, when Topp et al. (2008, p. XXII) remove the influence of resource depletion and the investment lag, they conclude that mining MFP in Australia has not declined precipitously but actually has continued to grow since 2000 at more or less the same rate as since the mid-1980s. Unfortunately, they do not indicate if this is the case as well for Australia's copper industry alone.

Bradley and Sharpe (2009) focus on the Canadian mining industry, which they break down into coal mining, metal ore mining, and non-metallic mineral mining. MFP in metal mining, which presumably more or less reflects trends in copper mining, rose on average 2.12 percent a year over the $1989-2000$ and then fell on average 1.75 percent a year over the 2000-2006 period. So, as in Chile, the United States, and Australia, we find productivity after rising for years falling over the past decade.

After exploring various possible explanations for the recent drop, they ascribe some of the decline in labor productivity to a drop in capital intensity or the amount of capital available per worker. With that caveat, however, the main culprit according to their analysis has been the rise in metal prices. In particular, they 
highlight the fact that higher prices encourage firms to exploit marginal resources that previously were uneconomic. To this, we could add the various other reasons discussed earlier that cause productivity to fall below its secular trend when mineral markets are booming.

Of particular interest is a figure from their study reproduced here as Figure 3. It shows for the Canadian metal ore mining industry trends in MFP, labor productivity, and metal prices (measured by the implicit price deflator for metal mining) over the years 1989 to 2006. The negative correlation between the two productivity measures and prices is quite apparent. When prices fall, productivity rises and vice versa.

\section{PRODUCTIVITY IN THE ALUMINUM INDUSTRY}

The largest aluminum producing countries are China, Russia, Canada, the United States, and Australia. Unfortunately, productivity studies of this industry are rather rare commodities. The one important exception for our purposes is Blomberg and Jonsson (2007), which is discussed below.

This dearth of studies, particularly those that focus on the years since 2003, is troubling. There are good reasons to suspect (a) that productivity trends for the aluminum industry have followed a different path over the past decade than those for copper, iron ore, and coal and (b) that the important forces governing productivity changes differ as well. First, the aluminum market has not experienced a boom in prices of anywhere near the magnitude of those for the other three commodities. It is true that between 2000 and 2006 real aluminum prices rose by 
about 40 percent. However, by 2012 they had fallen back to about their 2000 level. Second, while aluminum production depends on bauxite mining, mining costs on average account for only a very small portion -10 percent, more or less-of the total costs of producing aluminum. In this respect, aluminum is more like steel than iron ore, copper, or coal.

As a result, depletion and ore quality are likely to play a much more modest role in aluminum productivity trends over the long run. In addition, and of particular interest for our purposes, one would expect over the short run to find much less of a drop in productivity for aluminum than for copper, iron ore, and coal, if our central hypothesis is correct-namely, that much or all of the dramatic decline in productivity for copper, iron ore, and coal over the past decade is cyclical and due to higher prices.

Figure 4 suggests that this is indeed the case. While real aluminum prices rose and then fell over the decade, labor productivity in aluminum smelting (measured in terms of aluminum output per manhour) rose in all five of the countries shown. The increases were particularly dramatic for China and Russia, presumably because productivity was quite poor in both countries at the start of the decade. However, even the more modest increases of 15 to 25 percent in Australia, Canada, and the United States over the decade stands in sharp contrast to the substantial declines in productivity that these countries experienced in their copper, iron ore, and coal mining industries.

It is true that the aluminum productivity figures reflect trends only in aluminum smelting. For aluminum production as a whole-bauxite mining, refining, 
and smelting — the figures may not be quite so favorable. However, given that smelting accounts for around 70 percent of total cost of producing aluminum metal, the differences in productivity trends for aluminum smelting alone and aluminum metal production as a whole are not likely to be great.

Blomberg and Jonsson (2007), the recent study of productivity in the aluminum industry noted above, assesses MFP at 118 aluminum smelters over the 1993-2003 period. The methodology, which employs data envelopment analysis techniques and Malmquist indices, is able to estimate how much of the change in MFP is due to the introduction of new technology and how much to improvements in efficiency (defined as the improvements by smelters that lag behind the most efficient smelters).

The results for all 118 smelters are shown in Figure 5. Overall MFP increased by about 10 percent with technological change (what Blomberg and Jonsson call technical change) accounting for roughly two-thirds of this increase and improvements in efficiency (what Blomberg and Jonsson call technical efficiency change) contributing the rest. Interestingly, the figure suggests that these two determinants of MFP are somewhat offsetting: when one is pushing MFP higher, the influence of the other is neutral or declining. This probably is not surprising. When new technology is allowing the best smelters to increase their MFP rapidly, the less efficient smelters are likely to fall further behind. Then, when there is little new technology, the laggards have an opportunity to catch up.

These findings, it is important to note, apply just to the 118 smelters in the study sample. Smelters entering or exiting the industry during the 1993-2003 
period were excluded from the sample. Presumably those that left the industry on balance had high costs and hence low MFP, while those that entered the industry had high productivity since new smelters presumably incorporate the latest technology. As a result, the rise in productivity for the industry as whole may have been greater than 10 percent. However, many of the new smelters entering the industry were in China where productivity is relatively low. So it is not certain that productivity growth for the entire industry exceeded 10 percent.

Blomberg and Jonsson also examine regional differences in productivity growth. Of particular interest for our purposes, they hypothesize that productivity growth will be greatest in North America, Oceania, and Western Europe, regions where smelting capacity is stagnant or declining due high electricity and labor costs. To remain competitive and avoid closure, they suggest that smelters in these regions will have a particularly strong incentive to improve productivity in order to reduce their costs. Moreover, they expect most of this productivity improvement will come from better efficiency rather than new technology. The latter is largely embodied in new capacity, and little of the world's new smelting capacity was being built in these regions.

In contrast, they expect slower productivity growth in China, the Commonwealth of Independent States (CIS), and Africa and the Middle East. In these regions, smelters were more competitive and hence more interested in expanding production and capacity than in promoting productivity. In addition, the low cost of both labor and electricity reduced the incentives to adopt new input-saving technologies. Moreover, since smelter capacity was expanding in these regions, 
Blomberg and Jonsson expect that much of the increase in MFP that does occur will be due to new technologies embodied in new smelters.

Their results, shown in Table 3, largely though not completely support these expectations. Productivity growth is above the average in North America and Oceania. In China and the CIS it is below average. However, productivity growth in Europe is lower and in Africa and the Middle East higher than the average, which runs counter to their expectations. In addition, technological change in all six regions contributes more to MFP growth than do improvements in efficiency. This is consistent with their expectations for China, CIS, and Africa and the Middle East but not for North America, Oceania, and Western Europe.

For our purposes the Blomberg and Jonsson study is of interest because it provides additional support for the necessity-is-the-mother-of-invention perspective on the cyclical influence of innovation and new technology on productivity.

\section{PRODUCTIVITY IN THE IRON ORE INDUSTRY}

The largest iron ore mining countries are China, Australia, and Brazil. Other important producers include India, Russia, Ukraine, South Africa, the United States, and Canada. The available studies of productivity growth in this industry focus on Australia, Canada, and the United States.

Only a couple of these works cover the years since the early 2000s. The first of these, Topp et al. (2008), examines productivity in the Australian iron ore industry over the 1974-2007 period. Figure 6, which is reproduced from this study, 
shows that during the latter half of the 1970s and the first half of the 1980s MFP moved up and down but changed little over this decade. It then increased three fold during the second half of the 1980s. The 1990s was again a decade of ups and downs with little overall change. Then, between 2000 and 2007, as iron ore prices were surging upward, MFP dropped by nearly 30 percent.

Of particular importance for our purposes, all of this recent decline in MFP can according to Topp et al. be attributed to cyclical effects, rather than secular determinants. Of particular importance is the lag between when new investments are undertaken and when the resulting new capacity comes on stream (and begins contributing to production and productivity growth). As Figure 6 shows, when the trend in MFP is adjusted to remove this capital effect (what earlier sections of this study have referred to as the investment lag), instead of declining by nearly a third, MFP actually rises modestly over the 2000-2007 period.

In Canada, Bradley and Sharpe (2009, p. 31) find that the iron ore industry experienced an average increase in labor productivity of 3.10 percent a year over the 1997-2000 period and then suffered a slight decline between 2000 and 2006 (the last year of their analysis) of 0.28 percent a year. During the latter period prices almost tripled. So, in Canada as in Australia the jump in prices in recent years is associated with a decline in productivity growth.

Two earlier studies of productivity developments in iron ore mining provide some interesting insights. The first by Galdón-Sánchez and Schmitz (2002) explores the hypothesis that an increase in competitive pressure, the result of a sharp decline in the market price, stimulates productivity growth. To test this hypothesis they 
examine the world iron ore industry in the early 1980s following the collapse of world steel production and in turn iron ore prices. They define an increase in competitive pressure as an increase in the probability of a mine's closure. At the time mines in the Atlantic Basin with the exception of those in Brazil had higher costs and hence experienced a greater threat to survival than mines in the Pacific Basin.

The study then analyzes data on production and productivity for mines in Australia, Brazil, India, Canada, France, South Africa, Sweden, and the United States. Since the increase in competitive pressure was less for the first three of these countries than for the remainder, the hypothesis advanced expects that Canada, France, South Africa, Sweden, and the United States should enjoy greater productivity growth during the latter half of the 1980s into the early years of the 1990s than Australia, Brazil, and India. Figure 7, reproduced from this study, shows that this is indeed the case. Except for France, productivity surges sooner and more in the former countries. France is an exception because iron ore mining in this country basically responded to the crisis by shutting down.

The second study (Schmitz, 2005) focuses on iron ore mining in the Great Lakes region of Canada and the United States. For nearly a century producers in this area were protected from outside competition by the costs of transporting iron ore from more remote regions. In the early 1980s, however, as a result of major technological advances in shipping low-cost bulk commodities such as coal and iron ore, Brazilian producers began offering iron ore in Chicago and other steel 
producing centers in the Great Lakes region at prices considerably below those of the nearby Canadian and U.S. firms.

The Canadian and U.S. producers responded by doubling within a few years their labor productivity, which as Figures 8 and 9 show had changed little over the preceding decade. After examining various possible reasons for this jump, Schmitz concludes that most of the productivity gains were the result of changes in work practices. These changes not only diminished overstaffing but significantly reduced the time that equipment was down for repair and maintenance. Why were these changes made in the early and late 1980s and not earlier? The answer in part is that management before the 1980s was under much less pressure to make changes. In addition, organized labor had incentives to accept such changes only after rising imports from abroad seriously threatened the survival of the Great Lakes mines and in turn their jobs.

\section{PRODUCTIVITY IN THE COAL INDUSTRY}

The major coal producing countries are China, the United States, Australia, India, Russia, South Africa, and Indonesia. The available productivity studies largely focus on Australia, Canada, and the United States. The picture they paint has many of the same features found for copper and iron ore.

In most of these countries, LP and MFP rise during the 1980s and 1990s and then fall sharply during the 2000s. In Australia, for example, as the heavy solid line in Figure 10 shows, MFP more than doubles between 1986 and 2000. It then 
declines and by 2006-2007 is some 25 percent below its 2000 peak. Labor productivity in this country follows similar trends (Topp et al., 2008, Figure 2.6).

Bradley and Sharpe (2009, p. 16) provide similar data for the coal mining industry in Canada. They show that MFP growth there averaged 9.47 percent a year over the 1989-2000 period but then turned negative, averaging a minus 2.87 percent a year over the 2000-2007 period. The comparable figures for labor productivity—a plus 11.53 and a minus 4.56—reflect an even more dramatic reversal (Bradley and Sharpe, 2009, p. 14).

In both Australia and Canada, it appears that much, perhaps even all, of the recent decline in productivity can be attributed to the sharp rise in coal prices. In their analysis, Topp el al. (2008) isolate and measure the importance of resource depletion and capital effects on productivity trends in the Australian coal industry. Resource depletion is measured by the ratio of raw coal (the quantity extracted) to saleable coal (the quantity ultimately available for sale). The capital effects reflect the lags between the time investments in new capacity are undertaken (that is, when they are added to the capital stock for measuring MFP) and the time the new capacity starts to add to production.

As Figure 10 shows, resource depletion accounts for a small part of the decline in MFP in the Australian coal industry between 2000 and 2007. The capital effects are of much greater importance. Indeed, once MFP is adjusted to remove both the capital effects and the depletion, MFP actually rises over the 2000-2007 period. The capital effects, of course, are cyclical or temporary. Eventually, the 
recent investments in new mine capacity stimulated by higher coal prices will add to production, causing MFP to rise.

In Canada, Bradley and Sharpe (2009) similarly attribute much of the decline in productivity in the coal industry since 2001 to the rise in prices. Figure 11, reproduced from their study, is particularly interesting for our purposes. It shows the growth in MFP, labor productivity, and prices (approximated by the implicit price deflator for coal mining) for the coal industry in Canada over the 1989-2006 period. In discussing this figure, Bradley and Sharpe (2009, p. 29) highlight the inverse correlation between productivity and prices:

The implicit price deflator for the coal mining industry group was stable from 1989 to 1997. Between 1997 and 2000, the coal deflator dropped by 23 per cent and TFP in the coal industries increased by 40 per cent. Since 2000 the price of coal has increased sharply, especially since 2004, while TFP in coal mining declined between 2000 and 2006 after peaking in 2001.

A similar drop in productivity, also associated with a sharp jump in the coal price, occurred in the industry back in the mid-1970s. The rise in price at that time reflected the worldwide increase in coal demand due to the OPEC-induced jump in oil prices. Many studies have examined this decline in coal productivity. They provide some interesting insights as well.

Ellerman et al. (2001), which employs a very extensive and unique data set for the U.S. coal mining industry, is of particular interest. Figure 12, which comes from this work, shows MFP (the TFP index) and real coal prices over the 1947-1991 period. Between 1947 and 1970, real prices declined and productivity rose. In 1971 prices started to rise. They experience a major jump in 1974, peaked in 1975, but 
remained quite high until about 1980 . Productivity meanwhile suffered a sharp decline during the 1970s. By 1979, it was nearly 40 percent below its 1970 level. The 1980s then provided another reversal: real coal prices fell by about 50 percent, and productivity resumed its upward march, as in the 1950s and 1960s. By 1991, productivity had nearly recovered its 40 percent loss during the 1970 s.

In commenting on these trends and the findings of their analysis, Ellerman et al. (2001, p. 405) point out:

During the 1970s nearly everything seemed to conspire to reduce labor productivity, but the largest effect was attributable to the rising price of coal. The higher marginal revenue product of labor justified applying more labor to the task, and both statistics and anecdotes suggest that the first response of coal-mine operators was almost literally to throw labor (and other inputs) at the coal face. The inevitable result was lower productivity. The only phenomenon countering these productivity-depressing trends was the persistent improvement embodied in each successive vintage of new mines.... By the end of the 1970s, this source of productivity improvement was 15 percent above the 1972 level, but even this was more than overwhelmed by the combined effect of the other negative factors.

In short, new technology embodied in the plant and equipment of new mines continued to push productivity up over the 1970s as it had during the two preceding decades, but the negative cyclical effects associated with the jump in coal prices were far more powerful. So productivity declined over this era.

The tendency of high prices to keep inefficient mines in operations, to push production at high quality mines beyond their optimum levels, and in other ways to reduce productivity is a consistent theme in studies of coal productivity in the 1970s, 1980s, and 1990s. Smith (2004), for example, begins the abstract for his study with the following: 
The purpose of this report is to uncover the factors behind what has been a very strong productivity performance from the coal mining industry in Canada over the past four decades. It is found that the real price movements have had a substantial impact on productivity growth in the coal mining industry in Canada. The real price of coal increased sharply in the 1970s due to higher demand caused by the oil price shock. This increased the profitability of sites of marginal quality and thereby led to operations on less productive sites than those in production at that point. This had the effect of lowering the average productivity of the overall industry. However, since the 1970s, the real price of coal has fallen steadily, reversing this effect and hence contributing to the high productivity growth of the 1980s and 1990s.

Other inquiries that highlight the influence of coal price on productivity include the works by Darmstadter (1999) and Flynn (2000) of the U.S. coal mining industry, and the analysis by Humphris (1999) of the Australian coal mining industry.

The available studies do identify other factors affecting productivity that are either one-off events or more secular in nature. These include government regulations, the switch to longwall mining and other technological advances, the movement from underground to surface operations, labor unrest, and management innovations. Still, the persistent finding that productivity trends have moved inversely with real prices in all the major coal producing countries for which studies are available strongly suggests that the current declines in MFP and LP have a large cyclical component. When prices start to fall, productivity may once again trend upward.

\section{CONCLUSIONS AND IMPLICATIONS}


Over the past decade, many mineral commodity producers have suffered sharp declines in labor and multifactor productivity. These declines, moreover, followed two decades or so of rising productivity.

Many believe that this development reflects a reversal in the historic ability of new technology to counter the negative influence of depletion. Growth in China and other emerging markets along with the surge in demand from these countries for mineral commodities, they contend, is making it impossible for new technology to keep mining productivity from declining. This, they argue, is a structural break that will persist indefinitely into the future.

It is still too early to know for certain whether this explanation for the recent drop in mining productivity will ultimately prove valid. This study, however, examines a considerable amount of conceptual and empirical information that suggests most—perhaps all—of the recent decline in mining productivity may be cyclical, the result of the recent boom in mineral commodity markets, rather than secular and long term.

The conceptual analysis begins by examining the determinants of mining productivity—innovation and new technology, resource depletion, government regulations, labor quality, investment lags, economies of scale, capacity utilization, and strikes, accidents, and other work stoppages. The first two of these, as just noted, largely govern the long-run secular trends in productivity. The others for the most part cause productivity to fall below its secular trend when mineral commodity markets are strong and vice versa. Even the first two determinants- 
innovation and resource depletion—have important cyclical influences that push productivity below and above its trend as mineral prices rise and fall.

The conceptual analysis also explores cause and effect relationships that exist between commodity prices and productivity. In the short run when commodity markets are soft and idle capacity exists, producers strive to reduce costs by raising productivity. This shifts the supply curve downward, causing prices to fall further. So cause and effect runs in both directions and in a manner that accentuates the market decline. In the short run when commodity markets are booming and production is constrained by existing capacity, shifts in demand cause changes in price, which in turn cause productivity to rise or fall. Here, cause and effect runs mostly from prices to productivity with higher prices causing lower productivity. Over the long run, cause and effect again runs in both directions. Lower productivity causes prices to rise. This encourages the development of new technologies that enhance productivity, which alleviates the original price increase. So, in this case the two tend to mitigate, rather than accentuate, each other. In all three of these situations, prices and productivity are correlated. When prices change, so does productivity.

While the conceptual analysis highlights the reasons why the recent drop in mining productivity could be largely or entirely cyclical, the available studies of mining productivity in the copper, aluminum, iron ore, and coal industries provide considerable empirical support for this possibility.

When mineral prices are low and mines are facing closure, management and labor are much more likely to work together to bring costs down and improve 
productivity. This they do by altering work rules, introducing innovations and new technologies, and other means. The experience of the U.S. copper industry and the North American iron ore industry shows that such efforts have dramatically improved productivity when mineral commodity markets are depressed. The aluminum industry also provides support for the necessity-is-the-mother-ofinvention view of the cyclical influence of innovation and new technology on productivity.

On the other hand, when mineral markets are strong and prices are high, the pressure to reduce cost and enhance productivity is much weaker. New producers have an incentive to expand production despite higher costs to take advantage of the higher prices. They push capacity utilization beyond its optimal level. As our review of the Chilean copper industry illustrates, strikes and mine accidents can also adversely affect productivity during such periods.

If, as the evidence suggests, mining productivity over the past decade has largely fallen as a result of higher prices and booming markets, the implications are important. First, when the boom is over, mining productivity is likely to recover. Indeed, this occurred in the second half of 2008 and early 2009 when the Great Recession for a period sharply reduced the prices for copper and other mineral commodities.

Second, the recent decline in productivity does not necessarily mean that mineral commodity prices will rise over the long run or even remain at their current high levels. When productivity recovers, costs will fall, and this will cause mineral commodity prices in real terms to decline. This calls into question investments in 
new mining capacity whose profitability depends on prices remaining at their current high levels over the next 20 to 40 years.

Third, the long-standing debate over the terms of trade of primary product exporting countries is likely to continue. While Chile, Peru, Australia, and Canada are currently enjoying a strong improvement in their terms of trade, they and other mineral exporting countries should not count on this favorable development continuing indefinitely.

Finally, the recent decline in mining productivity, fortunately, does not necessarily mean that depletion has become a more serious threat. Historically, innovation and new technology have offset the negative effects of depletion on productivity and the cost of producing mineral commodities. If the recent decline in productivity and rise in commodity prices are largely a temporary phenomenon associated with booming commodity markets, this beneficial relationship between new technologies and depletion may continue to prevail over the foreseeable future.

\section{REFERENCES}

Aydin, H. and Tilton, J.E. 2000. Mineral endowment, labor productivity, and comparative advantage in mining, Resource and Energy Economics, Vol. 22, pp. 281293.

Blomberg, J. and Jonsson, B. 2007. Regional differences in productivity growth in the primary aluminium industry, in Blomberg, J., Essays on the Economics of the Aluminium Industry, PhD dissertation, Lulea University of Technology, Division of Business Administration and Social Sciences, Lulea.

Bradley, C. and Sharp, A. 2009. A Detailed Analysis of the Productivity Performance of Mining in Canada, CSLS Research Report 2009-7, September. 
Cochilco. annual. Anuario de Estadísticas del Cobre Y Otros Minerales, Comisión Chilena de Cobre, Santiago. Available at www.cochilco.cl/productos/anuario.asp.

Darmstadter, J. 1999. Innovation and productivity in U.S. Coal Mining, in Productivity in Natural Resource Industries, edited by Simpson, R.D., Resources for the Future, Washington, DC.

Ellerman, A.D., Stoker, T.M. and Berndt, E.R. 2001. Sources of Productivity Growth in the American Coal Industry 1972-95, in New Developments in Productivity Analysis, edited by Hulten, D.R., Dean, E.R. and Harper, M.J., University of Chicago Press, Chicago, IL.

Flynn, E.J. 2000. Impact of Technological Change and Productivity on the Coal Market, Issues in Midterm Analysis and Forecasting, U.S. Energy Information Administration, Washington, DC.

Galdón-Sánchez, J.E. and Schmitz, Jr., J.A. 2002. Competitive pressure and labor productivity: World iron ore markets in the 1980's, American Economic Review, Vol. 92, no. 4 (September), pp. 1222-1235.

Garcia, P., Knights, P.F. and Tilton, J.E. 2000. Measuring labor productivity in mining, Minerals and Energy, Vol. 15, No. 1, 31-39.

Garcia, P., Knights, P.F. and Tilton, J.E. 2001. Labor productivity and comparative advantage in mining: The copper industry in Chile, Resources Policy, Vol. 27, pp. 97105.

Humphris, R.D. 1999. The future of coal: Mining costs \& productivity, in The Future Role of Coal: Markets, Supply and the Environment, Organization for Economic Cooperation and Development and the International Energy Agency, Paris and Washington, DC, pp. 83-88.

Jara, J.J., Perez, P. and Villalobos, P. 2010. Good deposits are not enough: Mining labor productivity analysis in the copper industry in Chile and Peru 1992-2009, Resources Policy, Vol. 35, pp. 247-256.

Krugman, P. 1994. The Age of Diminished Expectations, MIT Press, Cambridge, MA.

Ortega Haye, J. 2010. The Modest Response of Copper Mine Production to Rising Prices Over the 2000-2008 Period, PhD dissertation, Pontificia Universidad Catolica de Chile, Santiago.

Prebisch, R. 1949. El Desarrollo Economico de la America Latina y sus Principales Problemas, report E/CN.12/89, United Nations, Economic and Social Council, Economic Commission for Latin America. 
Ritter, A., Almushary, M. and O'Reilly, P. 2011. Productivity growth in the U.S. copper industry, unpublished paper, Colorado School of Mines, Division of Economics and Business, Golden, CO.

Schmitz, Jr., J.A. 2005. What determines productivity? Lessons from the dramatic recovery of the U.S. and Canadian iron ore industries following their early 1980s crisis, Journal of Political Economy, Vol. 113, No. 3, pp. 582-625.

Singer, H.W. 1950. The distribution of gains between investing and borrowing countries, American Economic Review, Vol. 40, No. 2, pp. 472-485.

Smith, J. 2004. Productivity Trends in the Coal Mining Industry in Canada, Centre for the Study of Living Standards Research Report 2004-07, Ottawa, Ontario.

Syverson, C. 2011. What determines productivity? Journal of Economic Literature, Vol. 49, No. 2, pp. 326-365.

Tilton, J.E. 2001. Labor productivity, costs, and mine survival during a recession, Resources Policy, Vol. 27, pp. 107-117.

Tilton, J.E. and Landsberg, H.H. 1999. Innovation, productivity growth, and the survival of the U.S. copper industry, in Productivity in Natural Resource Industries, edited by Simpson, R.D., Resources for the Future, Washington, DC.

Topp, V., Soames, L., Parham, D. and Bloch, H. 2008. Productivity in the Mining Industry: Measurement and Interpretation, Australian Government, Productivity Commission, Staff Working Paper, Melbourne, VIC.

\section{PRODUCTIVITY STUDIES}

\section{General}

Arsenault, J. and Sharp, A. 2008. An analysis of the causes of weak labour productivity growth in Canada since 2000, International Productivity Monitor, vol. 18, spring issue, pp. 14-39, Center for the Study of Living Standards, Ottawa, Canada.

Bellamy, D. and Pravica, L. 2011. Assessing the impact of driverless haul trucks in Australian surface mining, Resources Policy, Vol. 36, No. 2, pp. 149-58.

Bradley, C. and Sharp, A. 2009. A Detailed Analysis of the Productivity Performance of Mining in Canada, CSLS Research Report 2009-7, September. 
Berndt, E.R. and Fuss, M.A. 1986. Productivity measurement with adjustments for variation in capacity utilization and other forms of temporary equilibrium, Journal of Econometrics, Vol. 33, pp. 7-29.

CSLS (Centre for the Study of Living Standards). 2003. Productivity Trends in Natural Resources Industries in Canada, Research report number 2003-1, February.

CSLS (Centre for the Study of Living Standards). 2004. Report on Productivity Trends in Selected Natural Resource Industries in Canada, Research report number 2004-06, October.

Dixon, P.B. and McDonald, D. 1992. A decomposition of changes in labour productivity in Australia: 1970-71 to 1989-90, Economic Record, Vol. 62, pp. 105117.

Ergas, H. and Wright, M. 1994. Internationalisation, firm conduct and productivity, in P. Lowe and J. Dwyer (eds.), International Integration of the Australian Economy, Reserve Bank of Australia, Sydney.

Garcia, P., Knights, P.F. and Tilton, J.E. 2000. Measuring labor productivity in mining, Minerals and Energy, Vol. 15, pp. 31-39.

Green, A.G. and Green, M.A. 1987. Productivity and Labour Costs in the Ontario Metal Mining Industry -1975 to 1985: An Update, Mineral Policy Background Paper no. 25, Ontario Ministry of Natural Resources.

Gretton, P. and Fisher, B. 1997. Productivity Growth and Australian Manufacturing Industry, Industry Commission Staff Research Paper, AGPS, Canberra.

$\mathrm{Gu}, \mathrm{W}$. and Ho, M.S. 2000. A comparison of industrial productivity growth in Canada and the United States, American Economic Review, Vol. 90, No. 2, pp. 172-75.

Hall, R.E., and Jones, C.I. 1999. Why do some countries produce so much more output per worker than others? Quarterly Journal of Economics, Vol. 114, February, pp. 83-116.

Hayes, R.H. and Clark, K.B. 1986. Why some factories are more productive than others, Harvard Business Review, September-October, pp. 66-73.

Holmes, T.J. and Schmitz, Jr., J.A. 2010. Competition and productivity: A review of evidence, Annual Review of Economics, Vol. 2, No. 1, pp. 619-42.

Lasserre, P. and Ouellette, P. 1988. On measuring and comparing total factor productivities in extractive and non-extractive sectors, Canadian Journal of Economics, Vol. 21, No. 4, November. 
Loughton, B. 2011. Accounting for natural resource inputs in compiling mining industry MFP statistics, paper prepared for the $40^{\text {th }}$ Annual Conference of Economics, Australian Bureau of Statistics, Canberra.

Parry, I.W.H. 1999. Productivity trends in the natural resource industries, in Productivity in Natural Resource Industries, edited by Simpson, R.D., Resources for the Future, Washington, DC.

Prescott, E. 1998. Needed: A theory of total factor productivity, International Economic Review, Vol. 39, No. 3, pp. 525-551.

Productivity Commission. 2004. ICT Use and Productivity: A Synthesis from Studies of Australian Firms, Commission Research Paper, Canberra.

Sharpe, A. and Guilbaud, 0. 2005. Indicators of innovation in Canadian natural resource industries, CSLS Research report number 2005-03, May.

Sibma, K. and Cusworth, N. 2006. Western Australia's productivity paradox, Western Australian Economic Summary, No. 3, WA Department of Treasury and Finance, pp. 54-74.

Stollery, K.R. 1985. Productivity change in Canadian mining 1957-1979, Applied Economics, Vol. 17, pp. 543-558.

Syed, A. and Grafton, Q. 2011. Productivity growth in Australia's mining sector: An overview, Resources and Energy Quarterly, Vol. 1, No. 1, pp. 98-114.

Symeonidis, G. 2008. The effect of competition on wages and productivity: Evidence from the United Kingdom, Review of Economics and Statistics, Vol. 90, No. 1, pp. 13446.

Syverson, C. 2011. What determines productivity? Journal of Economic Literature, Vol. 49, No. 2, pp. 326-365.

Topp, V., Soames, L., Parham, D. and Bloch, H. 2008. Productivity in the Mining Industry: Measurement and Interpretation, Australian Government, Productivity Commission, Staff Working Paper, Melbourne, VIC.

Wedge, T.A. 1973. The effect of changing ore grade on the rates of change in the productivity of Canadian mining industries, The Canadian Mining and Metallurgical Bulletin, Vol. 66, pp. 64-66.

Zheng, S. and Bloch, H. 2010. Australia's Mining Productivity Paradox: Implications for MFP Measurement, Centre for Research in Applied Economics Working Paper 201012, Curtin Business School, Curtin University of Technology, Perth, WA. 


\section{The Copper Industry}

Aydin, H. and Tilton, J.E. 2000. Mineral endowment, labor productivity, and comparative advantage in mining, Resources and Energy Economics, Vol. 22, pp. 281293.

Garcia, P., Knights, P.F. and Tilton, J.E. 2001. Labor productivity and comparative advantage in mining: The copper industry of Chile, Resources Policy, Vol. 27, pp. 97105.

Jara, J.J., Perez, P. and Villalobos, P. 2010. Good deposits are not enough: Mining labor productivity analysis in the copper industry in Chile and Peru 1992-2009, Resources Policy, Vol. 35, pp. 247-256.

Ritter, A., Almushary, M. and O'Reilly, P. 2011. Productivity growth in the U.S. copper industry, unpublished paper, Colorado School of Mines, Division of Economics and Business, Golden, CO.

Tilton, J.E. 2001. Labor productivity, costs, and mine survival during a recession, Resources Policy, Vol. 27, pp. 107-117.

Tilton, J.E. and Landsberg, H.H. 1999. Innovation, productivity growth, and the survival of the U.S. copper industry, in Productivity in Natural Resource Industries, edited by Simpson, R.D., Resources for the Future, Washington, DC.

Young, D. 1991. Productivity and metal mining: Evidence from copper-mining firms, Applied Economics, Vol. 23, pp. 1853-1859.

\section{The Aluminum Industry}

Blomberg, J. and Jonsson, B. 2007. Regional differences in productivity growth in the primary aluminium industry, in Blomberg, J., Essays on the Economics of the Aluminium Industry, PhD dissertation, Lulea University of Technology, Division of Business Administration and Social Sciences, Lulea, Sweden.

\section{The Iron Ore Industry}

Galdón-Sánchez, J.E. and Schmitz, Jr., J.A. 2000. Threats to Industry Survival and Labor Productivity: World Iron-Ore Markets in the 1980s, Federal Reserve Bank of Minneapolis, Research Department Staff Report 263. 
Galdón-Sánchez, J.E. and Schmitz, Jr., J.A. 2002. Competitive pressure and labor productivity: World iron ore markets in the 1980's, American Economic Review, Vol. 92, No. 4 (September), pp. 1222-1235.

Galdón-Sánchez, J.E. and Schmitz, Jr., J.A. 2003. Competitive pressure and the labor productivity: World iron ore markets in the 1980s, Federal Reserve Bank of Minneapolis Quarterly Review, Vol. 27, No. 2 (Spring), pp. 9-23.

Hellmer, S. 1997. Competitive Strengthen in Iron Ore Production, unpublished PhD thesis, Lulea University of Technology, Lulea, Sweden.

Schmitz, Jr., J.A. 2005. What determines productivity? Lessons from the dramatic recovery of the U.S. and Canadian iron ore industries following their early 1980s crisis, Journal of Political Economy, Vol. 113, No. 3, pp. 582-625.

Schmitz, Jr., J.A. and Teixeira, A. 2008. Privatization's impact on private productivity: The case of Brazilian iron, Review of Economic Dynamics, Vol. 11, No. 4, pp. 745-760.

\section{The Coal Industry}

Azzalini, P., Bloch, H. and Haslehurst, P. 2007. Australian coal mining: Estimating technical change and resource rents in a translog cost function, in Conference Proceedings of the $30^{\text {th }}$ Conference of the International Association for Energy Economists, edited by School of Economics and Finance, Victoria University, Wellington, New Zealand, for Oceania Association for Energy Economics.

Berndt, E.R., Ellerman, A.D., Schennech, S. and Stoker, T.J. 2000. Panel Data Analysis of U.S. Coal Mine Productivity, MIT Center for Energy and Environmental Policy Research, Working Paper no. MIT-CEEPR WP-2000-004, March.

Boyd, G.A. 1984. Scale and Productivity in Coal Strip Mining, PhD dissertation, Southern Illinois University, Carbondale.

Boyd, G.A. 1987. Factor intensity and site geology as determinants of returns to scale in coal mining, Review of Economics ad Statistics, Vol. 69, No. 1, pp. 18-23.

Chezum, B. and Garen, J.E. 1998. Are union productivity effects overestimated? Evidence from coal mining, Applied Economics, Vol. 30, pp. 913-18.

Darmstadter, J. 1999. Innovation and productivity in U.S. Coal Mining, in Productivity in Natural Resource Industries, edited by Simpson, R.D., Resources for the Future, Washington, DC. 
Ellerman, A.D., Stoker, T.M. and Berndt, E.R. 1998. Sources of Productivity Growth in the American Coal Industry, MIT Center for Energy and Environmental Policy Research, Working Paper no. MIT-CEEPR WP-1998-004, March.

Ellerman, A.D., Stoker, T.M. and Berndt, E.R. 2001. Sources of Productivity Growth in the American Coal Industry 1972-95, in New Developments in Productivity Analysis, edited by Hulten, D.R., Dean, E.R. and Harper, M.J., University of Chicago Press, Chicago, IL.

Flynn, E.J. 2000. Impact of Technological Change and Productivity on the Coal Market, Issues in Midterm Analysis and Forecasting, U.S. Energy Information Administration, Washington, DC.

Humphris, R.D. 1999. The future of coal: Mining costs \& productivity, in The Future Role of Coal: Markets, Supply and the Environment, Organization for Economic Cooperation and Development and the International Energy Agency, Paris and Washington, DC, pp. 83-88.

Kulshreshtha, M. and Parikh, J. 2002. Study of efficiency and productivity growth in opencast and underground coal mining in India: A DEA analysis, Energy Economics, Vol. 24, pp. 439-53.

Naples, M.I. 1998. Technical and social determinants of productivity growth in bituminous coal mining, 1955-1980, Eastern Economic Journal, Vol. 24, No. 3, pp. $325-42$.

Pinnock, M. 1997. Productivity in Australian coal mines: How are we meeting the challenges? The Australian Coal Review, July. Available at www.Australiancoal.csiro.au/pdfs/Pinnock.pdf.

Pippenger, J. 1995. Competing with the big boys: Productivity and innovation at the Freedom Lignite Mine, Mining Engineering, April, pp. 333-45.

Rodriguez, X.A. and Arias, C. 2008. The effects of resource depletion on coal mining productivity, Energy Economics, Vol. 30, pp. 397-408.

Smith, J. 2004. Productivity Trends in the Coal Mining Industry in Canada, Centre for the Study of Living Standards Research Report 2004-07, Ottawa, Ontario.

\section{Other Mineral Industries}

Bradley, C. and Sharp, A. 2009. A Detailed Analysis of the Productivity Performance of Oil and Gas Extraction in Canada, CSLS Research Report 2009-8, September. 
Bridgman, B., Gomes, V. and Teixeira, A. 2011. Threatening to increase productivity: Evidence from Brazil's oil industry, World Development, Vol. 39, No. 8, pp. 1372-85.

CSLS (Centre for the Study of Living Standards). 2005. The Expansion Effect and Diminishing Returns: Labour Productivity in the US and Canadian Oil and Gas Industries, 1987-2002.

Demura, P. 1995. Productivity change in the Australian steel industry: BHP Steel 1982-1995, in Proceedings of a Conference: Productivity and Growth, Reserve Bank of Australia. Available at www.rba.gov.au/publications/1995/demura/pdf.

Ichniowski, C., Shaw, K. and Prennushi, G. 1997. The effects of human resource management practices on productivity: A study of steel finishing lines, American Economic Review, Vol. 87, June, pp. 291-313.

Managi, S., Opaluch, J.J., Jin, D. and Grigalunas, T.A. 2005. Stochastic frontier analysis of total factor productivity in the offshore oil and gas industry, Ecological Economics, Vol. 60, pp. 204-215.

Smith, J. 2004. The growth of diamond mining in Canada and implications of mining productivity, CSLS Research report 2004-09, October.

Syverson, C. 2004. Market structure and productivity: A concrete example, Journal of Political Economy, Vol. 112, December, pp. 1181-1222.

\section{FIGURES AND TABLES}


Figure 1. Short-Run Market Supply and Demand Curves for a Mineral Commodity

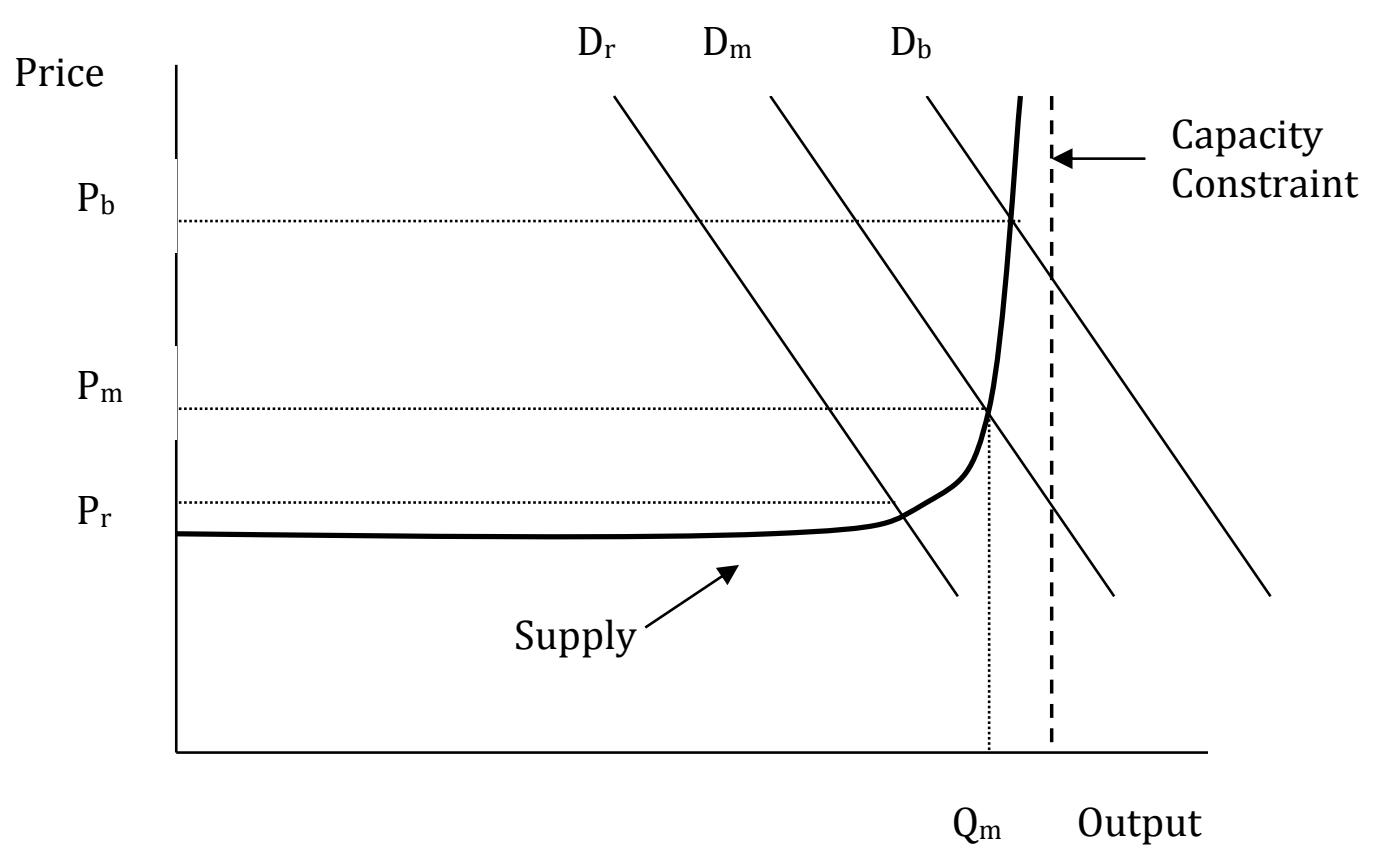

Figure 2. Long-Run Market Supply and Demand Curves for a Mineral Commodity

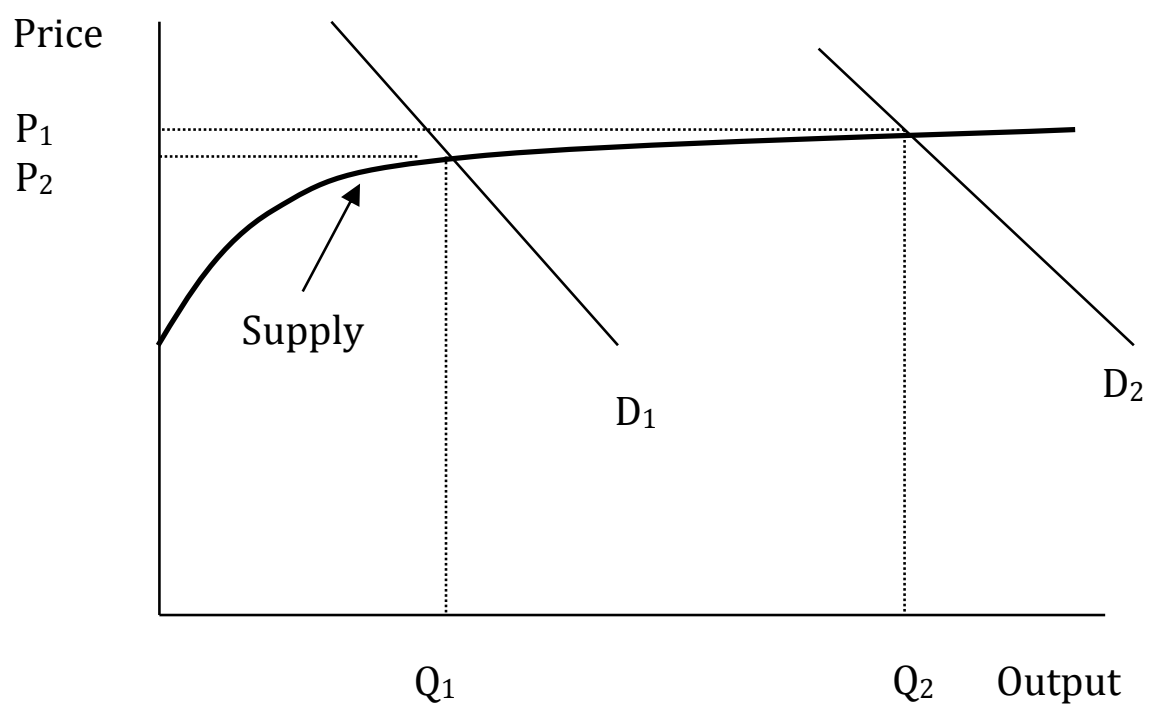


Figure 3. Prices and Productivity, Metal Ore Mining, Canada, 1989-2006 $(1989=100)$

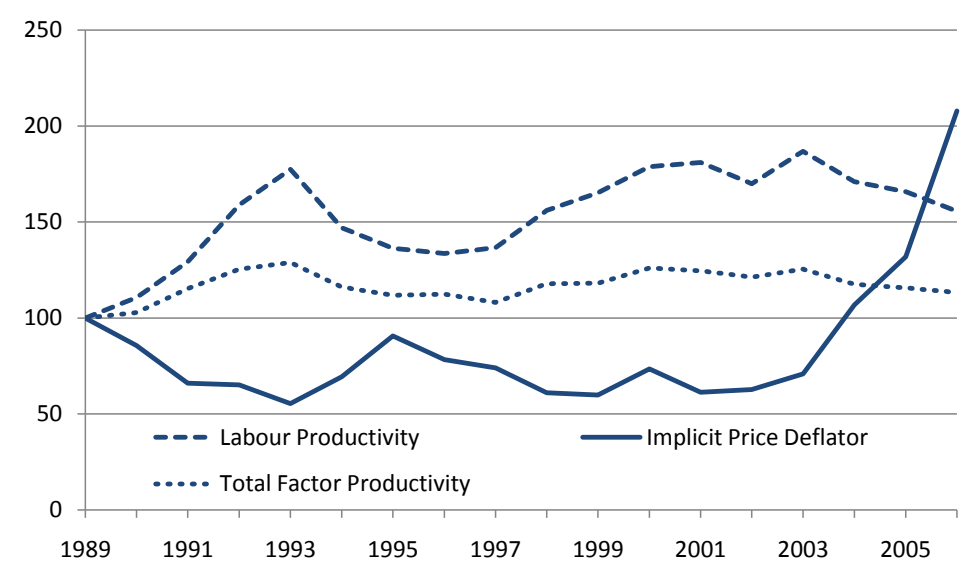

Source: Bradley and Sharpe, 2009, Chart 12.

Figure 4. Real Aluminum Prices and Labor Productivity in Tons of Aluminum Output Per Manhour for Australia, Canada, China, Russia, and the United States, 2000-2010 (2000 = 100)

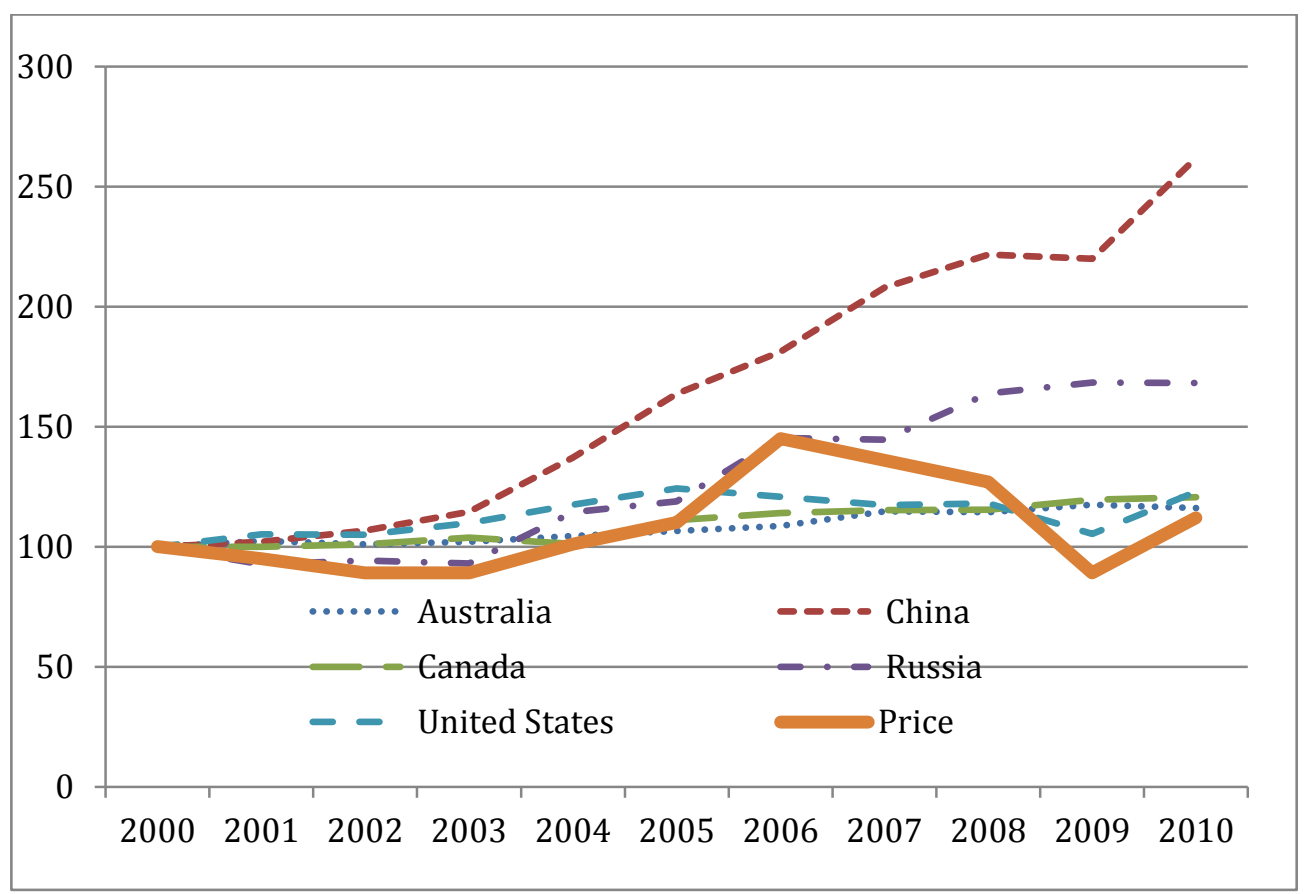

Sources: Labor productivity data (measured in manhours per ton) are from CRU (now part of Wood Mackenzie). Aluminum prices are from UNCTAD (the United Nations Conference on Trade and Development). 
Figure 5. Cumulative Change in Multiple Factor Productivity and its Components for 118 Aluminum Smelters, 1993-2003

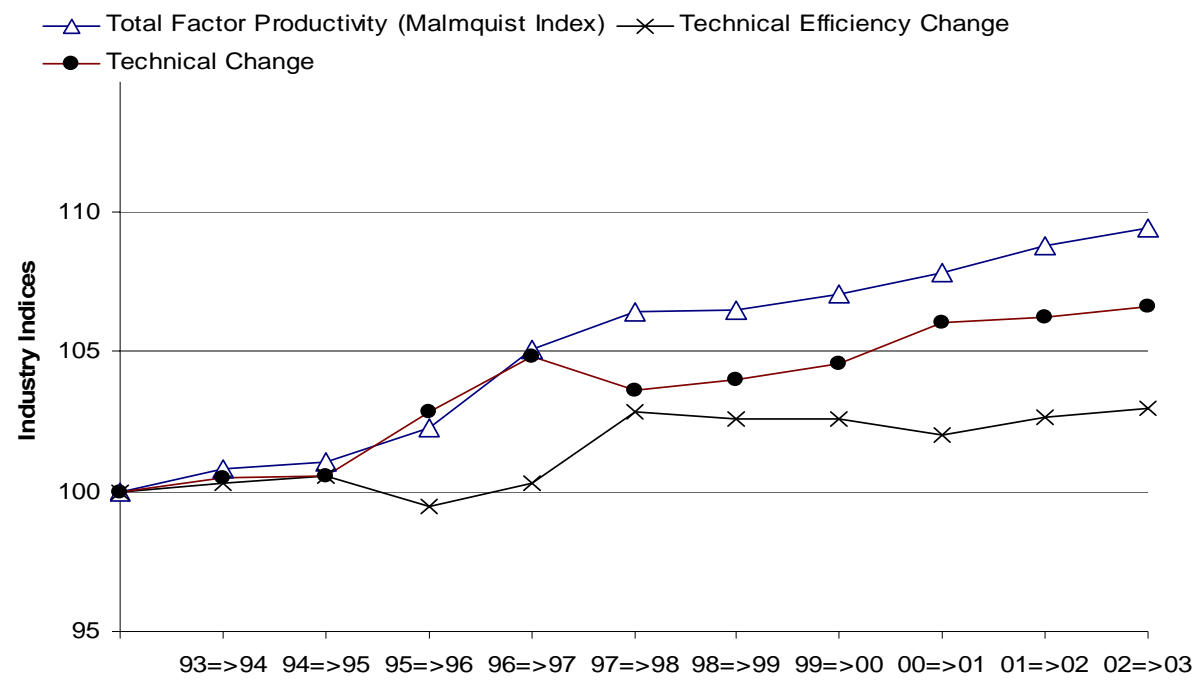

Source: Blomberg and Jonsson (2007), Figure 1.

Figure 6. Trends in MFP and MFP with Capital Effects Removed for the Australian Iron Ore Industry, 1974-75 to 2006-07 $(2000-01=100)$

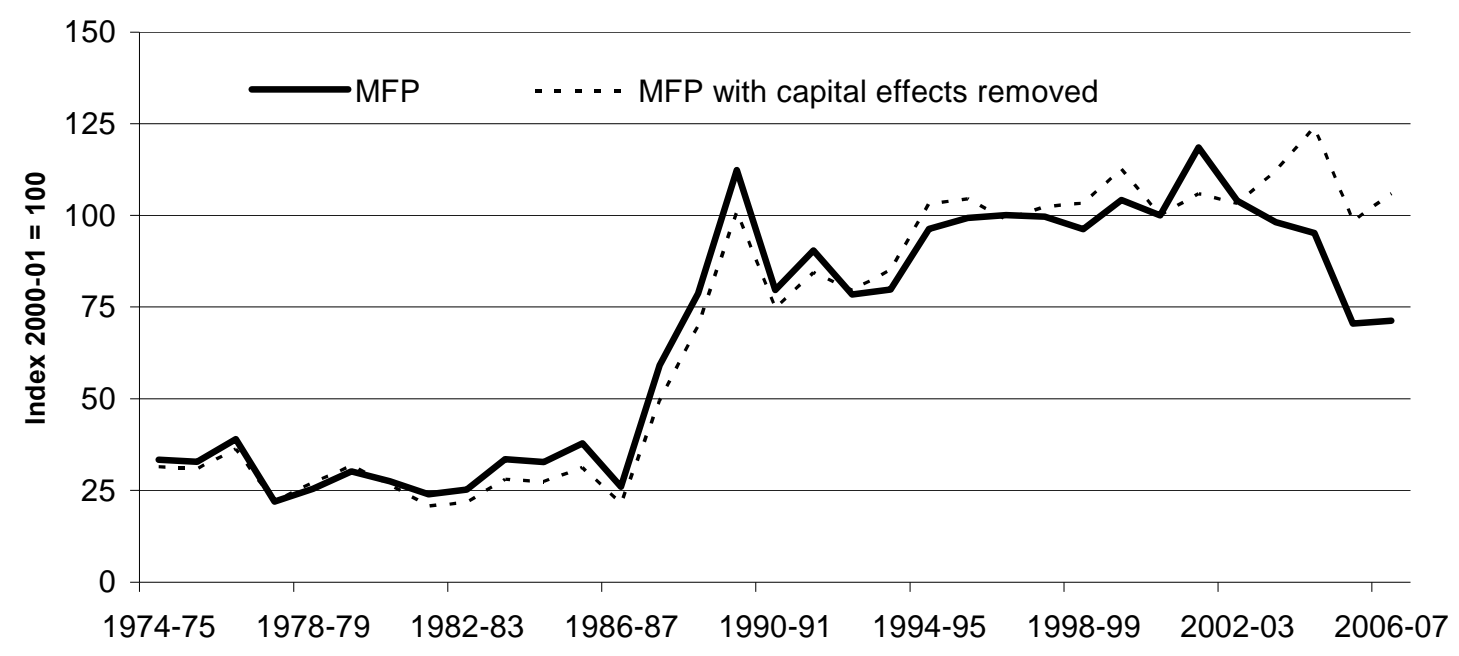

Source: Topp et al. (2008), p. 122. 
Figure 7. Iron Ore Production and Productivity $(1980=100)$ for Australia, Brazil, India, Canada, France, South Africa, Sweden, and the United States, 1960 to 1995

Australia

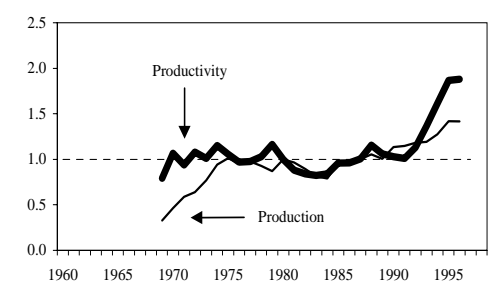

Brazil

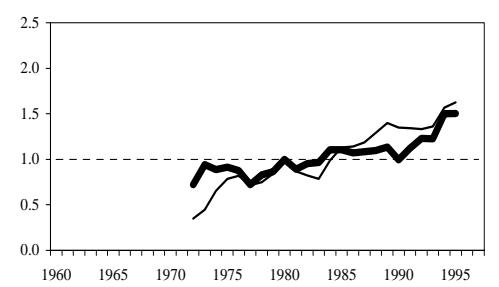

India

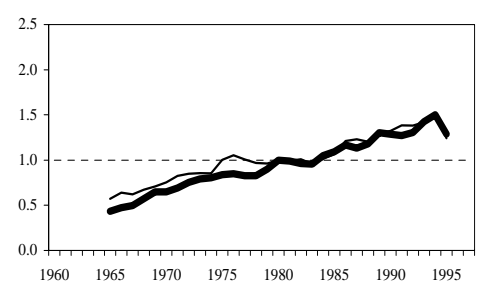

South Africa

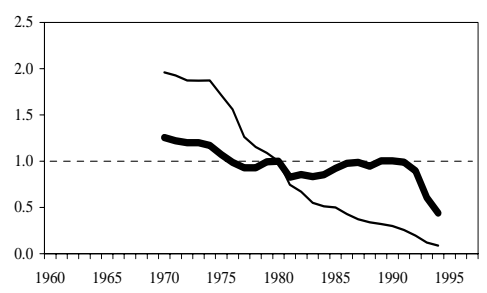

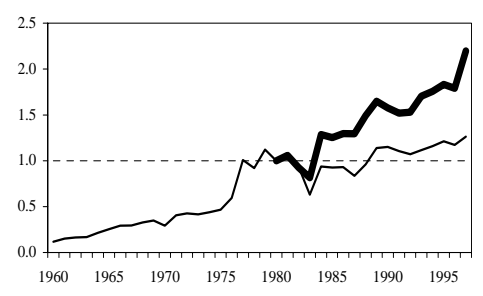

U.S.A.
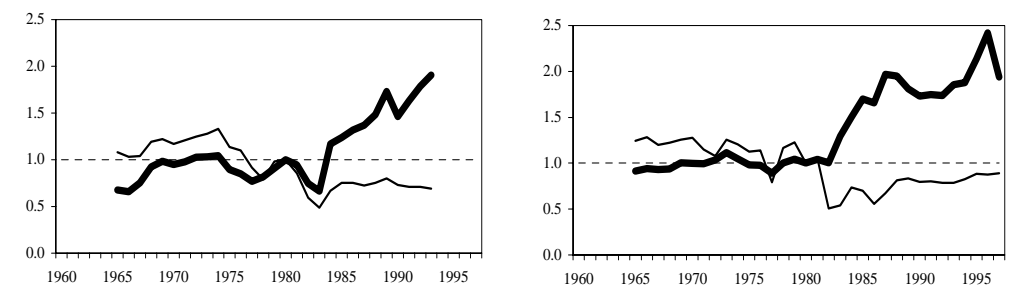

Source: Galdón-Sánchez and Schmitz (2002), p. 1231. 
Figure 8. Production and Productivity for the

U.S. Iron Ore Industry, 1970 to $1995(1980=100)$

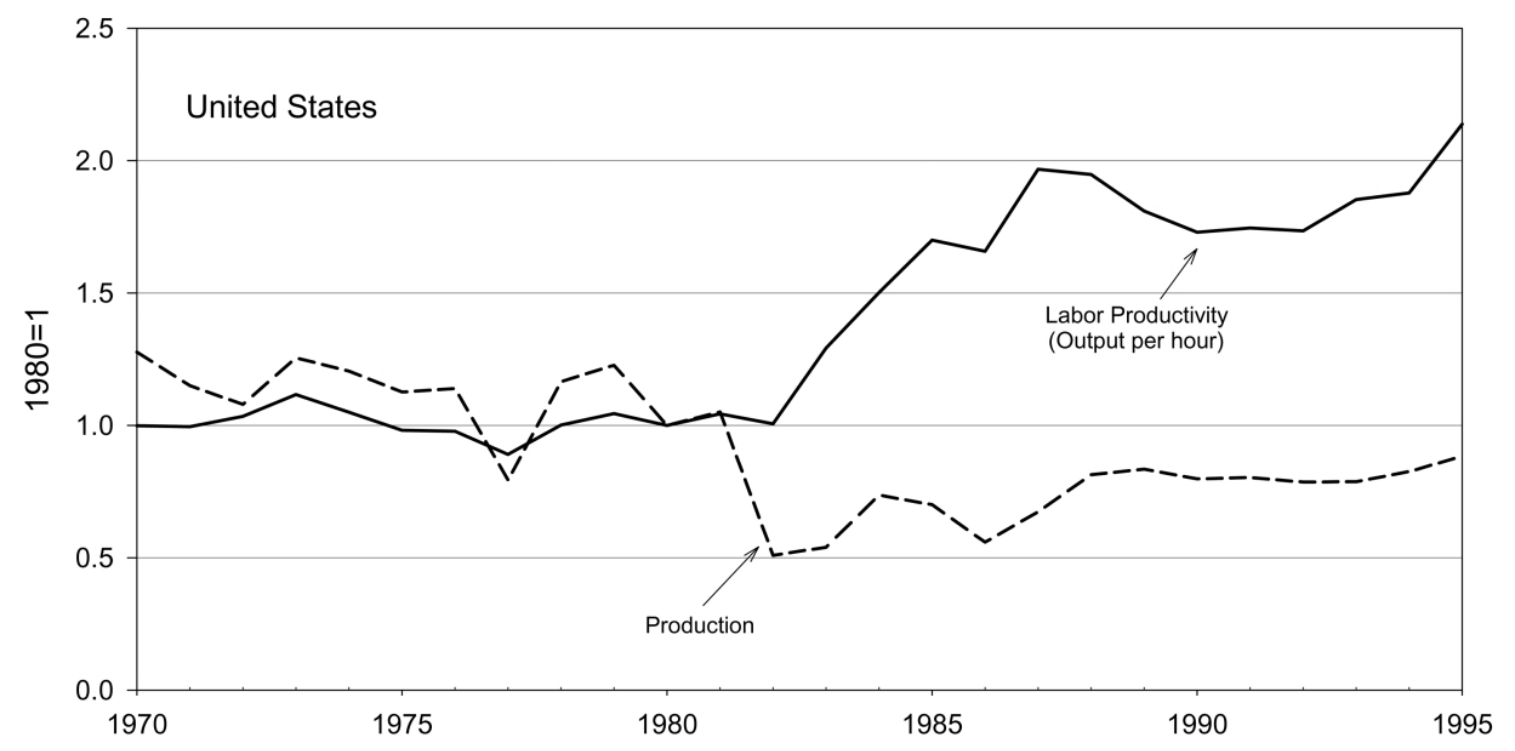

Source: Schmitz (2005), p. 594

Figure 9. Production and Productivity for the Canadian Iron Ore Industry, 1970 to 1995 (1980 = 100)

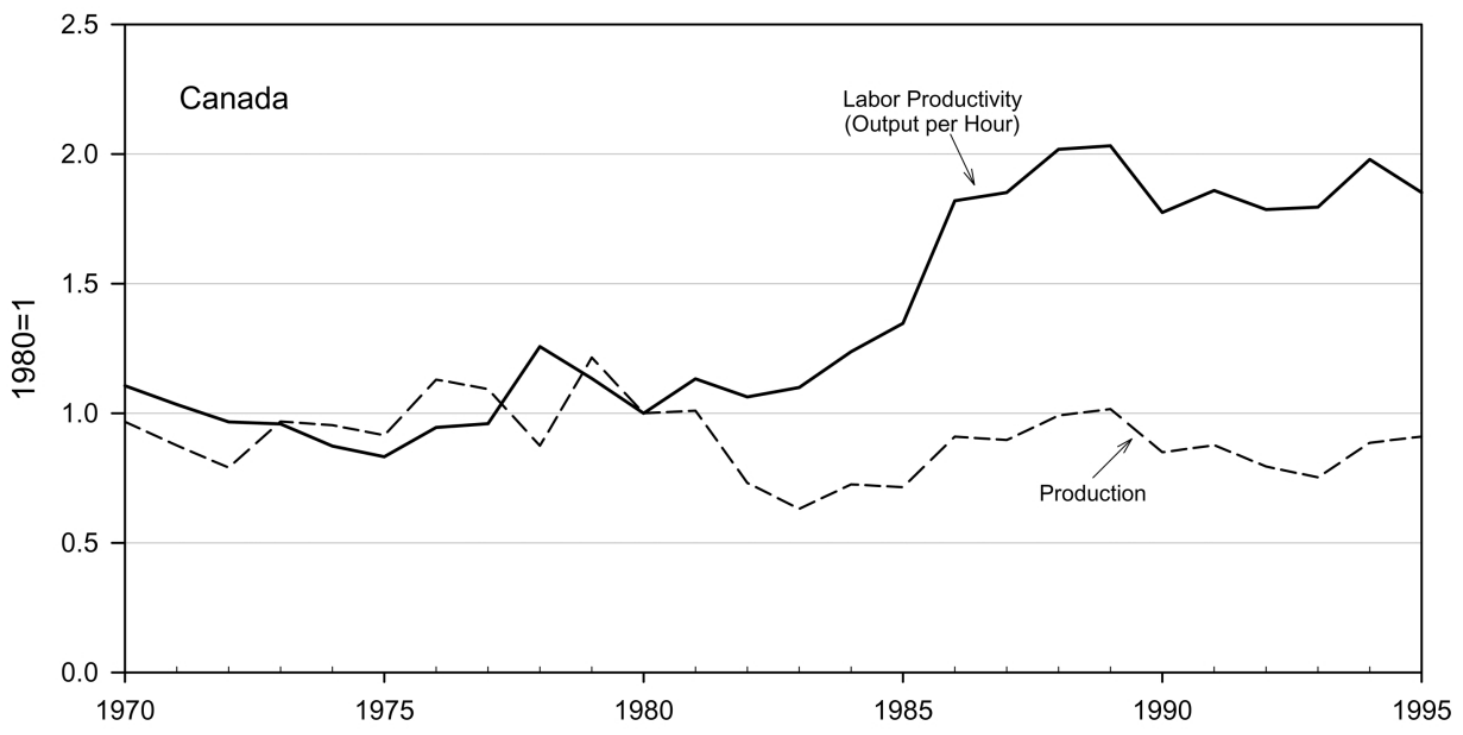

Source: Schmitz (2005), p. 595 
Figure 10. Multifactor Productivity in the Australia Coal Industry with and without Depletion and Capital Effects Removed, 1974-2007

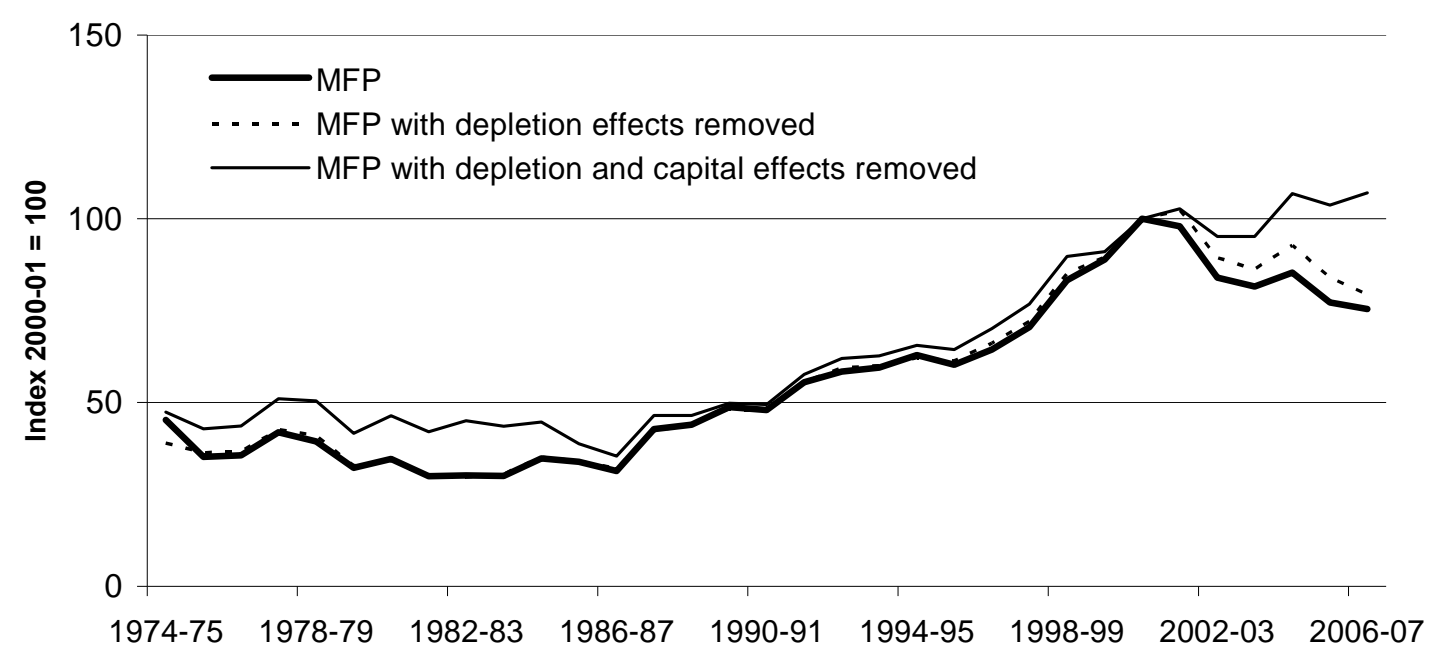

Source: Topp et al. (2008), Figure A.3, p. 116.

Figure 11. Multifactor Productivity, Labor Productivity, and Coal Prices in the Canadian Coal Mining Industry, 1989-2006

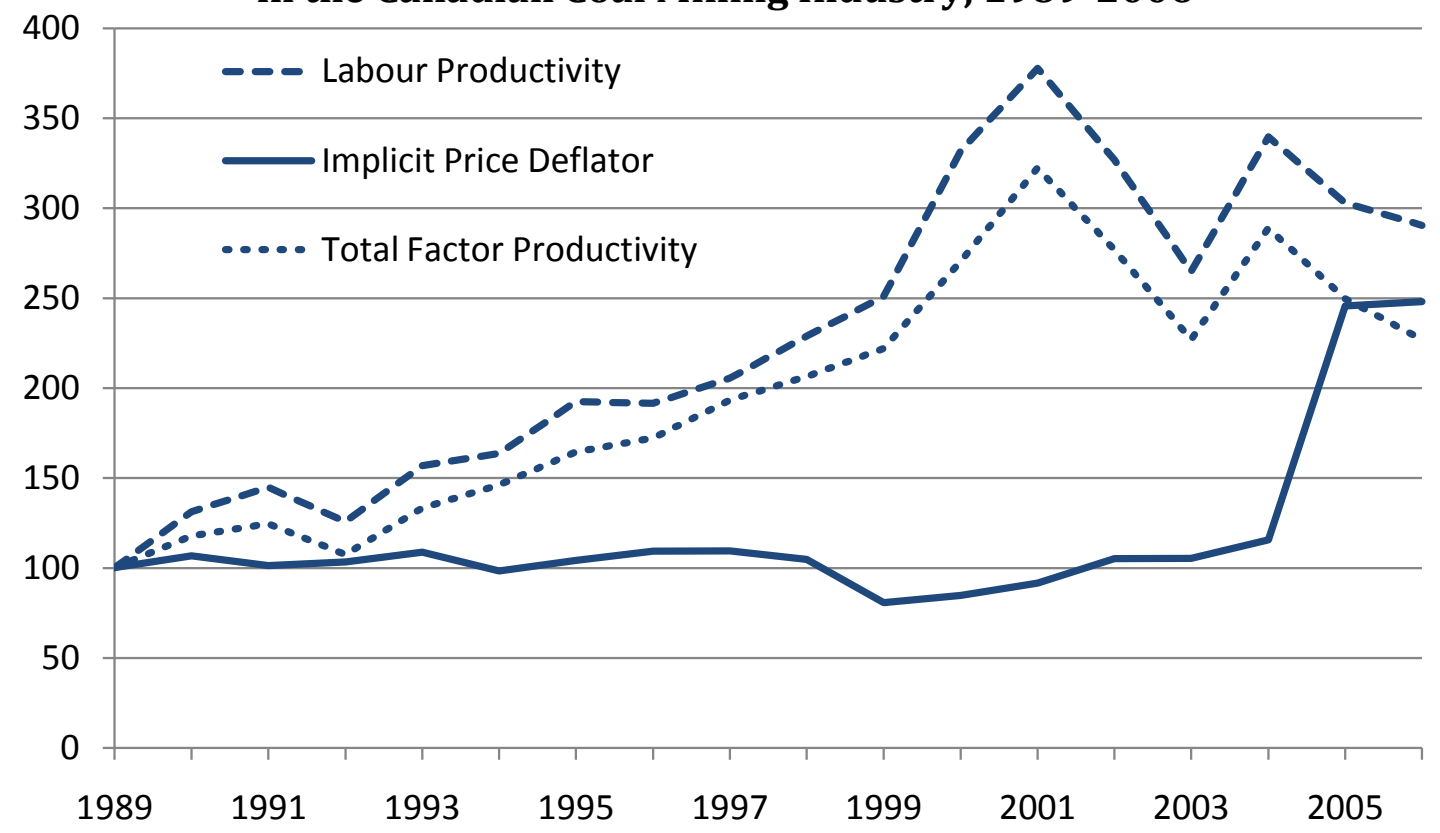

Source: Bradley and Sharpe (2009), Chart 11, p. 29. 
Figure 12. Price, Output, and Total Factor Productivity for the U.S. Coal Industry, 1947-1991

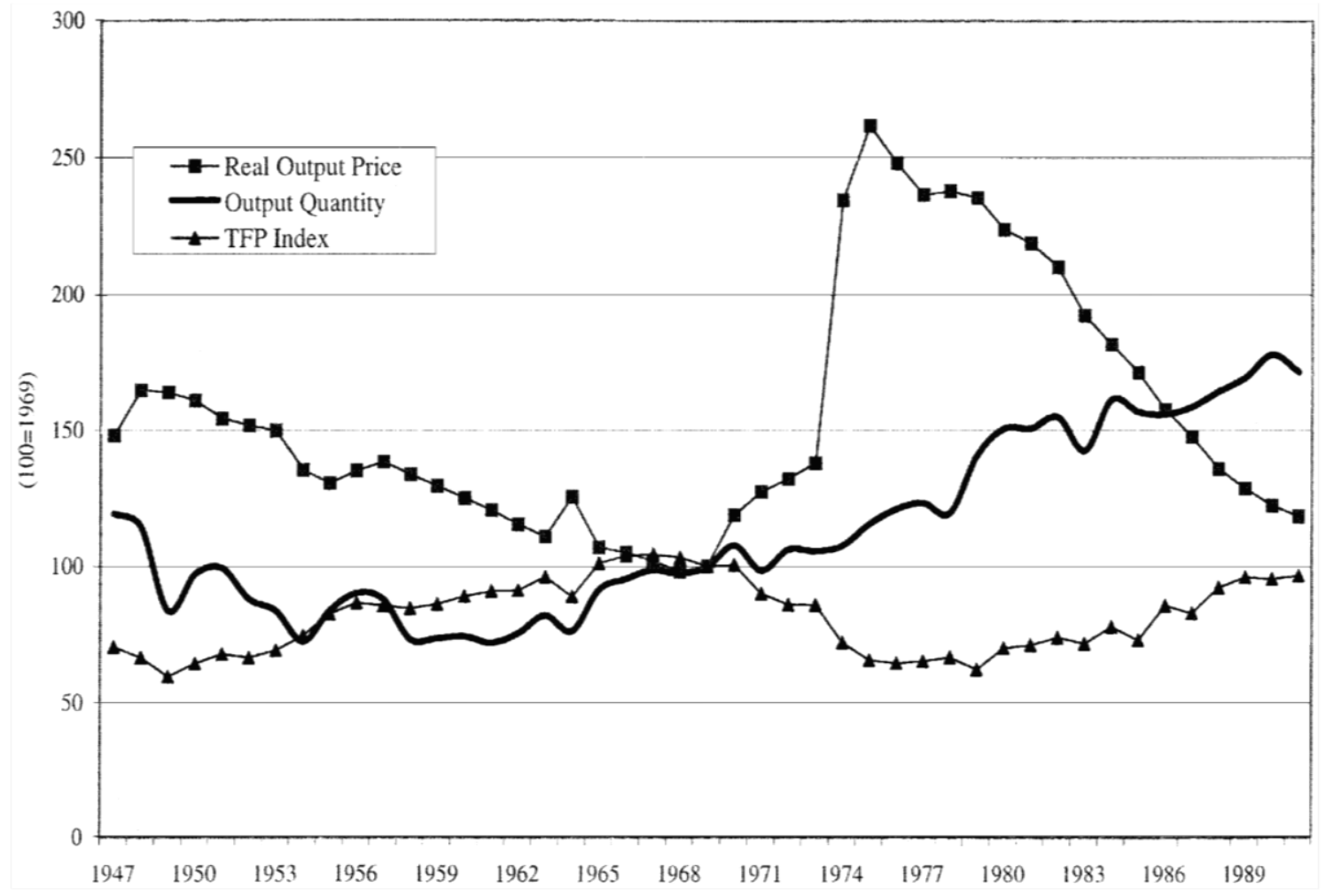

Source: Ellerman et al. (2001), Fig. 9.1, p. 375. 
Table 1. Own Workforce Productivity Index for Codelco and the Largest Private Copper Producing Companies in Chile, 2005-2012 $(2005=100)$

\begin{tabular}{lrrrrrrrr}
\hline Company & $\mathbf{2 0 0 5}$ & $\mathbf{2 0 0 6}$ & $\mathbf{2 0 0 7}$ & $\mathbf{2 0 0 8}$ & $\mathbf{2 0 0 9}$ & $\mathbf{2 0 1 0}$ & $\mathbf{2 0 1 1}$ & $\mathbf{2 0 1 2}$ \\
\hline & 100 & 97 & 112 & 88 & 76 & 72 & 52 & 67 \\
Escondida & 100 & 97 & 83 & 63 & 58 & 53 & 44 & 24 \\
Collahuasi & 100 & 97 & 79 & 86 & 77 & 94 & 89 & 81 \\
Los Pelambres & 100 & 96 & 91 & 80 & 74 & 65 & 61 & 71 \\
Anglo American* & 100 & 101 & 106 & 92 & 71 & 78 & 84 & 65 \\
Candalaria & 100 & 103 & 75 & 64 & 57 & 50 & 41 & 48 \\
El Abra & 100 & 119 & 111 & 98 & 98 & 102 & 90 & 87 \\
Zaldivar & 100 & 120 & 100 & 93 & 81 & 81 & 81 & 58 \\
Cerro Colorado & 100 & 100 & 97 & 88 & 107 & 92 & 64 & 62 \\
Quebrada Blanca & $\mathbf{1 0 0}$ & $\mathbf{9 9}$ & $\mathbf{9 8}$ & $\mathbf{8 2}$ & $\mathbf{7 4}$ & $\mathbf{7 2}$ & $\mathbf{6 0}$ & $\mathbf{5 9}$ \\
GMP-10 & 100 & 94 & 88 & 78 & 88 & 88 & 93 & 89 \\
Codelco & $\mathbf{1 0 0}$ & $\mathbf{9 7}$ & $\mathbf{9 6}$ & $\mathbf{8 4}$ & $\mathbf{8 1}$ & $\mathbf{8 0}$ & $\mathbf{7 5}$ & $\mathbf{7 4}$ \\
GMP-10 + Codelco & & & & & & & & \\
\hline
\end{tabular}

\section{Notes:}

*Includes Anglo American Sur and Anglo American Norte.

GMP-10 covers the 10 largest private copper producing companies in Chile.

Source: Cochilco (annual), Table 48.

Table 2. Average Copper Mining Grades in Chile, by Process Type, 2001-2010

2000200220042006200820102012

$\begin{array}{llllllll}\text { Concentrate } & 1.38 & 1.22 & 1.21 & 1.19 & 1.07 & 0.98 & 0.90 \\ \text { Leaching } & 1.13 & 1.04 & 0.98 & 0.91 & 0.94 & 0.82 & 0.84 \\ \text { Average } & 1.29 & 1.13 & 1.11 & 1.08 & 0.99 & 0.89 & 0.86\end{array}$

Source: Cochilco (annual), Table 47 
Table 3. Average Annual Change in Productivity and its Components for 118 Aluminum Smelters by Regions, 1993-2003

\begin{tabular}{l|ccc}
\hline \hline Region & $\begin{array}{c}\text { Technical } \\
\text { Efficiency } \\
\text { Change }\end{array}$ & $\begin{array}{c}\text { Technological } \\
\text { Change }\end{array}$ & TFP \\
\hline China & 1.002 & 1.078 & 1.080 \\
CIS & 0.992 & 1.071 & 1.054 \\
North America & 1.036 & 1.085 & 1.127 \\
Latin America & 1.044 & 1.061 & 1.107 \\
Oceania & 1.058 & 1.065 & 1.126 \\
West Europe & 1.018 & 1.069 & 1.089 \\
East Europe & 1.102 & 1.064 & 1.169 \\
Africa \& Middle East & 1.027 & 1.082 & 1.112 \\
Asia & 0.965 & 1.124 & 1.102 \\
Global average & 1.023 & 1.077 & 1.101 \\
\hline \hline
\end{tabular}

Source: Blomberg and Jonsson (2007), Table 4. 